\title{
Characterization of Landfill Leachates and Sediments in Major Cities of Indochina Peninsular Countries-Heavy Metal Partitioning in Municipal Solid Waste Leachate
}

\author{
Phetyasone Xaypanya ${ }^{1, *}$, Jiro Takemura ${ }^{1}$, Chart Chiemchaisri ${ }^{2}$, Hul Seingheng ${ }^{3}$ and \\ Maria Antonia N. Tanchuling ${ }^{4}$ \\ 1 Department of Civil and Environmental Engineering, Graduate School of Engineering, \\ Tokyo Institute of Technology, Tokyo 152-8550, Japan; takemura.j.aa@m.titech.ac.jp \\ 2 Department of Environmental Engineering, Faculty of Engineering, Kasetsart University, Bangkok 10900, \\ Thailand; fengccc@ku.ac.th \\ 3 Research and Innovation Center, Institute of Technology of Cambodia, PO Box 86 Russian Federation, \\ Phnom Penh 12000, Cambodia; hul@itc.edu.kh \\ 4 College of Engineering, University of the Philippines, Diliman 1101, Philippines; mntanchuling@up.edu.ph \\ * Correspondence: xaypanya.p.aa@m.titech.ac.jp; Tel.: +81 70 1598-5599
}

Received: 27 April 2018; Accepted: 31 May 2018; Published: 3 June 2018

\begin{abstract}
In this study, leachate and sediment samples were collected from the leachate drains, ponds and waste pits of three landfills in the Indochina peninsula to investigate the level of contamination of biochemical parameters, especially heavy metals. In-situ and laboratory measurements were conducted, together with site surveys to discuss the effects of site characteristics on leachate qualities. It was confirmed from the investigation that the changes in leachate qualities are mainly caused by the landfill site conditions, e.g., soil cover, the waste compaction level, waste thickness, dumping method, and leachate storage, and that these conditions lead to different levels of dilution and biochemical reaction of the leachate. Most of the biochemical parameters of the fresh leachates were greater than the effluent standards, and showed higher concentrations than those measured for the leachate in large storage ponds. The concentrations of the parameters were higher in the dry season than the wet season for all fresh leachate samples, but no significant seasonal difference was observed in the large leachate storage ponds. The majority of heavy metals were partitioned in the suspended solids, and no clear seasonal change of heavy metal contents was contained in the suspended solids and sediment samples.
\end{abstract}

Keywords: solid waste; landfill leachates; suspended solids; sediment; heavy metal; partitioning

\section{Introduction}

Landfill is a primary facility for municipal solid waste disposal in most countries, especially in the South East Asian region, where many countries are under developing country status, and some of them are still on the list of least-developed countries. However, these countries have been facing a linear increase of municipal solid waste and waste management problems [1]. The increase of resource consumption results in massive amounts of solid waste from various kinds of industries and domestic activities, which poses a significant threat to human health and the environment [2]. Leachate quality, quantity, and its characteristics are directly related to the waste management practices, climate conditions, and waste characteristics, as well as the landfill operation method, and the leachate can be a primary source of various contaminants and pollutions. Minimizing the risk to 
human health and the environment in the nearby communities is a severe concern for both sanitary landfills and open dumping facilities [3]. Also, the leachate quality is mainly influenced by waste characteristics, including the waste composition, age, and site operation methods such as compaction level, daily cover, pretreatment, liquid waste co-disposal, and quality and quantity of water entering the landfill. Moreover, another important factor is chemical reactions such as biodegradation, adsorption, hydrolysis, dissolution, dilution, partitioning, and precipitation [4]. The type and concentration level of the contaminants in the leachate depend on the manner of disposal together with the waste composition, as well as the waste segregation before its final disposal [5]. The leachate problem is worsened by the fact that many landfills in developing countries lack appropriate landfill facilities, such as bottom liner, leachate collection, and treatment systems; this increases the possibility of groundwater and surface water contamination [6]. In the most cases, landfill leachate consists of organic matter (biodegradable and non-bio degradable), inorganic pollutants and hazardous substances [7,8]. Hazardous substances in municipal solid waste (MSW) are presented in the form of paints, mercury-containing wastes, batteries, vehicle maintenance products, and many other diffuse products [7]. Solid waste disposal facilities such as open dumps, landfills, sanitary landfills, or incinerators represent a significant source of metals released into the environment [9-13]. In addition, the areas near or close to landfills have a higher possibility of groundwater contamination; this is due to most of the landfills and dumping facilities releasing a significant amount of leachate into their vicinity. The impacts of landfill leachate on the surface and groundwater have given rise to a number of studies in recent decades [14-16]. There are different levels of impact on human health and the environment depending on the type of landfill and their management. At the same time, the concentrations of some heavy metals often exceed the national and international organization standard limit $[17,18]$.

This study aims to assess landfill leachate and sediment qualities, discuss the dumped site conditions on the leachate qualities of the selected landfills. Also, the correlation for the related parameters are investigated, especially focusing on heavy metals and their partitioning behavior. All assessments were made on three major landfills in three countries located in the Indochina peninsular region, namely the Nonthaburi landfill (Nonthaburi Province, Thailand), the Dangkor landfill (Phnom Penh, Cambodia), and the KM-32 landfill (Vientiane, Laos).

\section{Study Sites and Methodologies}

\subsection{Site History and Characteristics}

The sites of the study are three landfills located in three different countries in the Indochina Peninsular region, the Nonthaburi landfill in Nonthaburi Province, Thailand, the Dangkor landfill in Phnom Penh, Cambodia and the KM-32 landfill in Vientiane, Laos. Nonthaburi is one of the provinces in the Bangkok Metropolitan region; the most densely populated next to Bangkok, and the other two landfills are located in the capital cities of the two countries. These three landfills serve as only one municipal solid waste (MSW) landfill for each city, with many basic similarities, such as climate and environmental condition, the lifestyle of the people, and the culture and beliefs of the people. Figure 1 shows the landfill locations, as well as the shape layout for each landfill, superimposed on the current image from the Google Earth free version. Information on the three landfills is summarized in Table 1. 


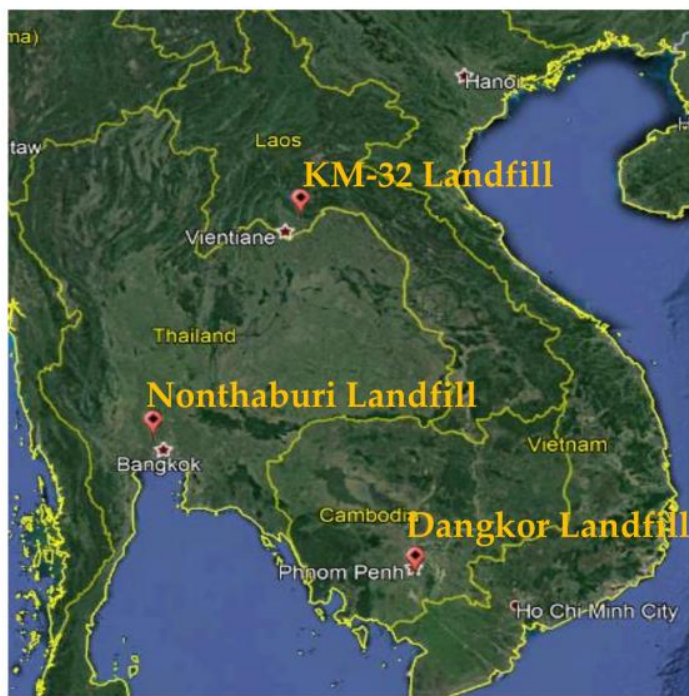

(a)

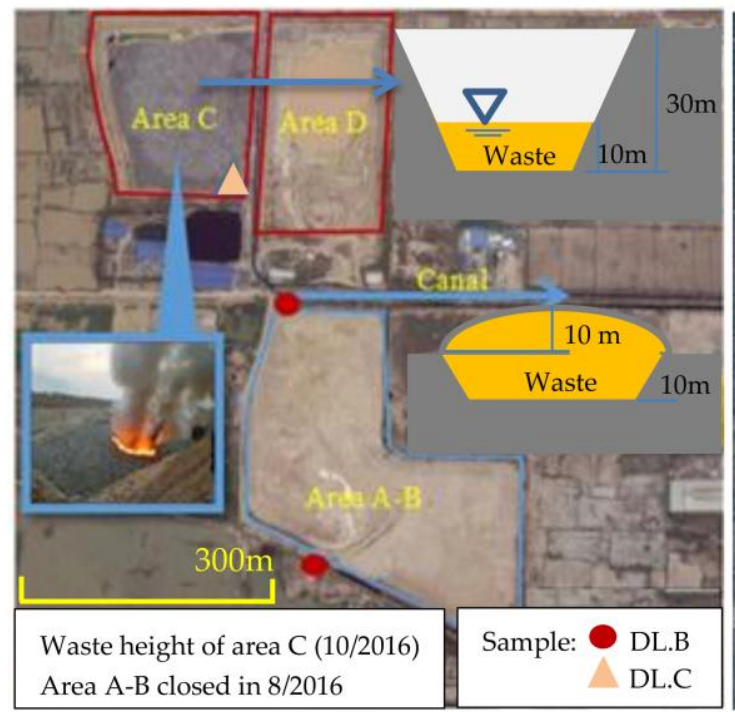

(c)

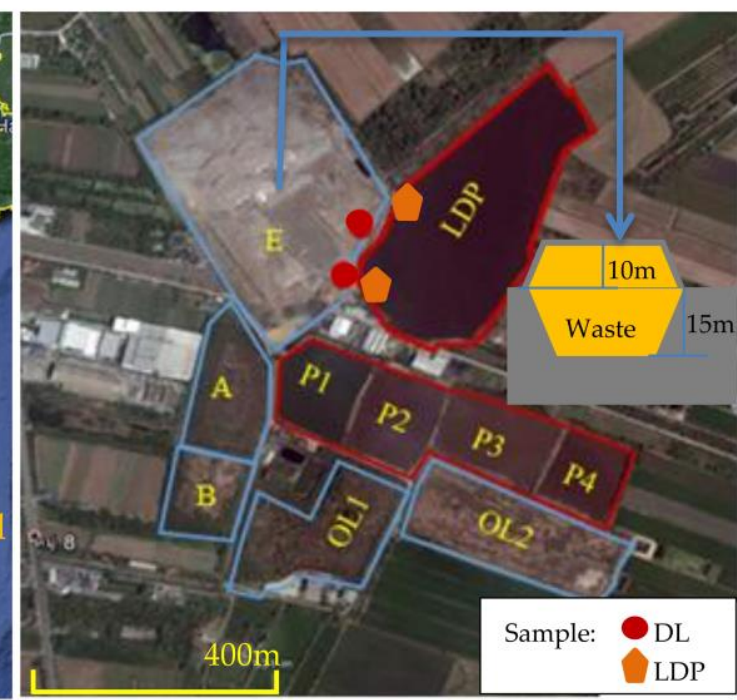

(b)

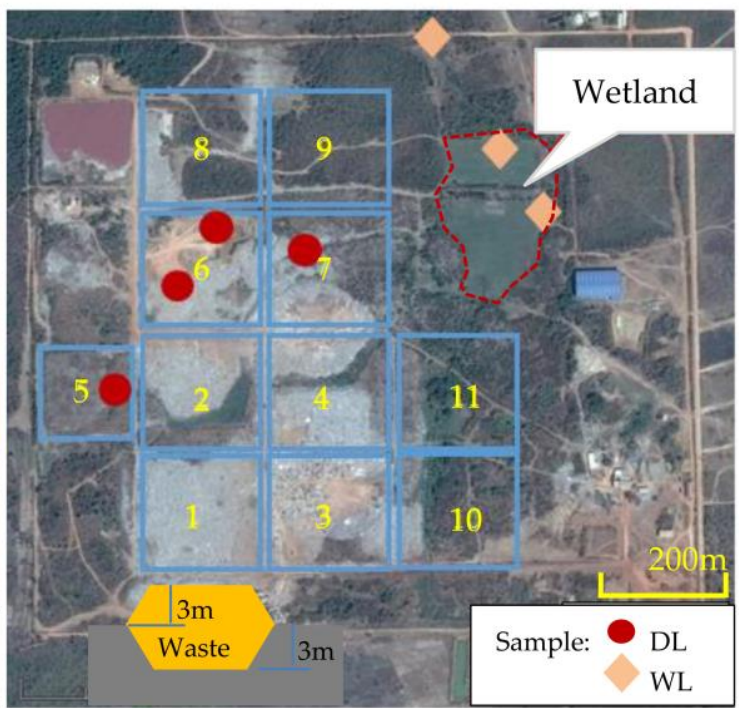

(d)

Figure 1. Locations of the study sites, and the landfill plan of the sampling points superimposed on the Google Earth image, the pit depth and waste height of the dumping facility. (a) Landfill location; (b) Nonthaburi landfill; (c) Dangkor landfill; (d) KM-32 landfill. DL: direct leachate; LDP: leachate discharge pond; DL.B: direct leachate from area B; DL.C: direct leachate from area C; WL: wetland.

Table 1. Summary of landfill information (as of March 2017).

\begin{tabular}{|c|c|c|c|}
\hline Items & Nonthaburi landfill, Thailand & Dangkor Landfill Cambodia & KM-32 Landfill Laos \\
\hline Coordination & $14^{\circ} 0^{\prime} 58^{\prime \prime} \mathrm{N}$ and $100^{\circ} 18^{\prime} 53^{\prime \prime} \mathrm{E}$ & $11^{\circ} 28^{\prime} 59^{\prime \prime} \mathrm{N}$ and $104^{\circ} 53^{\prime} 11^{\prime \prime} \mathrm{E}$ & $18^{\circ} 4^{\prime} 48^{\prime \prime} \mathrm{N}$ and $102^{\circ} 50^{\prime} 49^{\prime \prime} \mathrm{E}$ \\
\hline Year of operation & 1982 & 2009 & 2008 \\
\hline Waste received (tons/d) & 1300 & 1800 & 500 \\
\hline $\begin{array}{c}\text { Elevation (MSL-mean } \\
\text { sea level) }\end{array}$ & 5 & 11 & 190 \\
\hline Area of closed dumping pit (ha) & 34 & 11 & 24 \\
\hline Excavated/future area (ha) & 0 & 3.8 & 12 \\
\hline Depth of pit (m) & Old pit $=5 ; \mathrm{New}=15$ & Area $A, B=10 ; C, D=30$ & Pit No. $1-7=3$ \\
\hline H. of garbage from surface $(\mathrm{m})$ & Old $=4-5 ; \mathrm{New}=10$ & Area $A, B=10 ; C, D=0$ & Pit No. $1-7=3$ \\
\hline Volume of waste $\left(\mathrm{m}^{3}\right)$ & $8,488,000$ & $3,527,697$ & $1,840,000$ \\
\hline Volume of leachate $\left(\mathrm{m}^{3}\right)$ & $1,156,800$ & 356,800 & 180,000 \\
\hline
\end{tabular}


Table 1. Cont.

\begin{tabular}{|c|c|c|c|}
\hline Items & Nonthaburi landfill, Thailand & Dangkor Landfill Cambodia & KM-32 Landfill Laos \\
\hline Daily soil cover & Occasional & None & None \\
\hline Final soil cover & $80 \%$ & Area A-B $(100 \%)$, others $(0 \%)$ & None \\
\hline Avg_sunlight (hr/d) & $7.2[19]$ & $6.7^{*}$ & $6.9 * *$ \\
\hline Avg_temp (Celsius) & 24-32 [19] & $24-35^{*}$ & $23-30 * *$ \\
\hline Soil type (bottom soil) (m/s) & Clayey, $-\mathrm{K}=10^{-(9-10)}$ & Sandy Clay, $\mathrm{K}=10^{-(7-8)}$ & Clay $(\mathrm{CH}), \mathrm{K}=10^{-(9-10)}$ \\
\hline
\end{tabular}

\subsubsection{Nonthaburi Landfill}

The Nonthaburi landfill is about $60 \mathrm{~km}$ from the city center of Bangkok to the northwest, with an approximate area of $77 \mathrm{ha}$. According to the landfill authority, the average waste received daily was 800 tons/day in 2000, which increased by more than $60 \%$ up to 1300 tons/d in 2015. From 1982 to 2004, the landfill operated as an open dumping facility mainly in the old area (OL1), simple pits were dug for waste dumping and leachate storage. In 2004, areas A and B were developed as a sanitary landfill with a geomembrane liner and these areas received the garbage from 2005-2006. More than one million cubic meters of garbage have been transferred from the old area to the new area to stabilize the steep slope of the old dumping pile. From 2007-2009, the other old area (OL2) was operated as a semi-sanitary landfill by a local company. In August 2009, a new semi-sanitary landfill (area E) had started operation, and it is planned to be the last landfill area. Beside landfill $\mathrm{E}$, there is a large and deep pond. In the early stage of operation of area $\mathrm{E}$, this pond was a water reservoir, but it started to receive the leachate from landfill $\mathrm{E}$ and became a leachate discharge pond (LDP) in early 2012.

\subsubsection{Dangkor Landfill}

The Dangkor landfill in Phnom Penh is one of the largest dumpsites in Cambodia. The dumpsite occupies an area of 31.4 ha, located about $14 \mathrm{~km}$ from the Phnom Penh city center [20]. Starting its operation from August 2009, it received daily waste of about 1200 tons/day, which has rapidly increased to 1800 tons/d in 2015. There are two areas of zoning, Areas A-B and Areas C-D. Areas A-B with a pit depth of $10 \mathrm{~m}$ was opened from August 2009 and closed in Feb 2016, and covered by soil in October 2016. Area C (5.5 ha) was started right after the closing of Areas A-B. The pit depth of Area C is very deep, about $30 \mathrm{~m}$ below ground surface. In May 2016, a waste fire broke out in the deep pit, and many hundred thousand tons of garbage was burned. In the meantime, Area D was also excavated with a similar pit depth to Area $\mathrm{C}$, with an approximate area of 3.8 ha, extending the dumping capacity.

\subsubsection{KM-32 Landfill}

The KM-32 landfill is the biggest and only MSW disposal site in the Vientiane capital after the old landfill at KM-18 was closed. It started its operation in August 2008, with an approximate area of $100 \mathrm{ha}$, and the distance from the Vientiane capital city center is about $32 \mathrm{~km}$. The garbage volume accepted has continuously increased from 250 tons/d in 2008 to 500 tons/day in 2015. The dumping started with pits No.1 and No.2 in August 2008; dumping in pits No.3 and No.4 began in February 2009, while pit No.1 and No.2 were still active. Pit No.5 was designed to be the leachate pond, but the authorities decided to put the garbage into the pond instead of keeping it for leachate storage, and it was closed in September 2012. In late 2016, pits No.6 and No.7 were excavated, and some garbage has already been put in the pits. In the area planned for pits No.8-11, the excavation work has not started, but a small amount of garbage is piled in those areas. 


\subsubsection{The Similarity and Differences of the Sites}

The three landfills are all serving as the municipal solid waste disposal facility for each municipality, which have highly dense populations. Since no proper waste segregation system has been implemented, the detailed composition of the waste material including the source of hazardous substances has not been identified, which is common for household waste, as discussed by Slack et al. [7]. Another similarity is the geological condition, with soil with low permeability that function as a natural clay liner $[20,21]$. Importantly, thanks to the deep geological sublayer with low permeability, these three landfills use the same method of dumping, namely the excavation or trench method. Nonthaburi landfill has the longest history and stores the most significant leachate with five supporting ponds, sharing the leachate when needed. Although no active treatment is applied, such as aeration, these ponds are considered a leachate pre-treatment system, preventing the uncontrolled release of the leachate from the landfill. Dangkor landfill has the deepest pit of the active area as in Areas C and $\mathrm{D}$, about $30 \mathrm{~m}$ below the ground surface, which could increase the potential risk of groundwater contamination in the future. KM-32 landfill has the largest area of the three, and the landfill is separated into 11 segments with a shallow garbage layer of about $6 \mathrm{~m}$ ( $3 \mathrm{~m}$ pit depth and $3 \mathrm{~m}$ waste pile height). The leachate is drained to a natural wetland then flows out to the lower back area during the rainy season. No leachate is produced from the waste pile, and the wetland dries up during the dry season.

Based on the landfill guidelines of the United Nations Environment Programme (UNEP) [22], three landfill types are defined depending on the facilities and the dumping methods: (1) open dump; (2) controlled dump; and (3) sanitary landfill. From the site observation and information obtained from the site engineers, Nonthaburi landfill can be classified as a semi-sanitary landfill, while the Dangkor landfill and KM-32 landfill are considered as a controlled dump and open dump facilities, respectively.

\subsection{Solid Waste Characteristics}

Municipal solid waste (MSW) characteristics in the three countries are similar with regard to the major portion of organic compounds, as shown in Figure 2. Nonthaburi landfill has the highest percentage of organic waste, followed by the KM-32 and Dangkor landfills. The composition is also similar to those reported by other studies of other Association of Southeast Asian Nations (ASEAN) country landfills, which found the same range of organic portion in, for example, Indonesia, Malaysia, Myanmar and Vietnam [23-26]. Also, in other regions, such as Haiti and Bangladesh [27,28], the contained organic mixture is about $62 \%$ and $65 \%$. In central Nigeria, the organic compound ranged from 23.4 to $57.5 \%$ between low- and high-density population areas [29]. Wood/grass is counted as an organic material, and the KM-32 landfill accepted all kinds of waste, while Nonthaburi and Dangkor accept a minor amount of agricultural waste. The second largest component was plastic, ranging from 13 to $21 \%$, and the rest is distributed as smaller proportions.

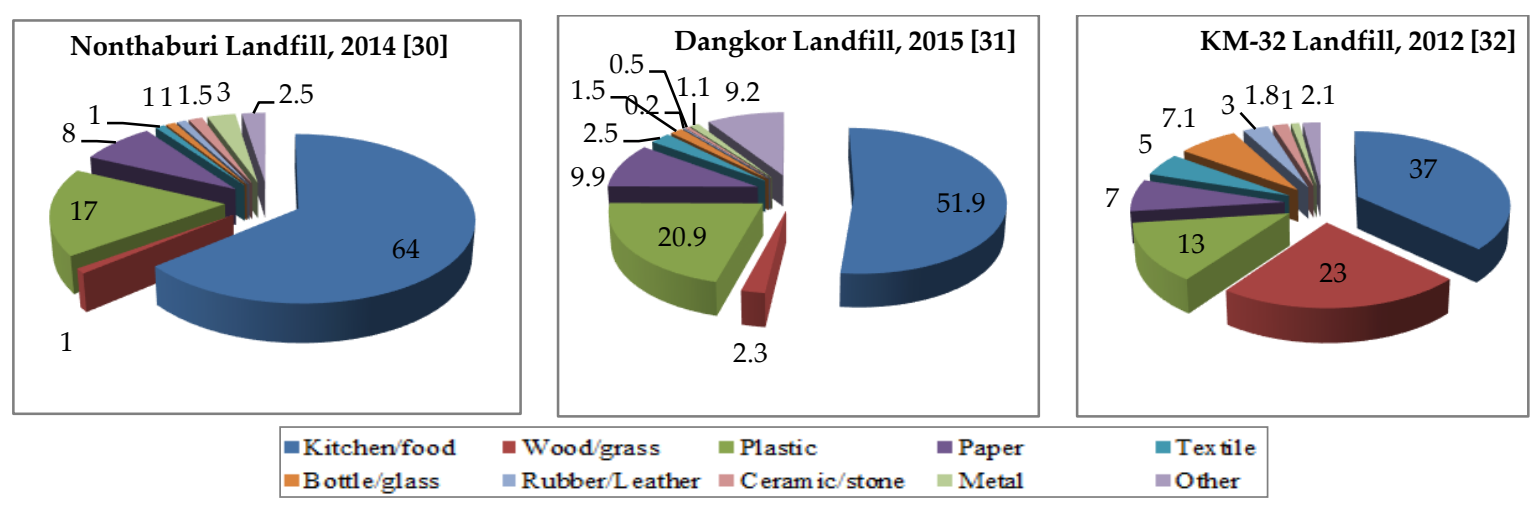

Figure 2. Waste composition in percent (\%) [30-32]. 


\subsection{Sampling Period and Location}

The sample collection at Nonthaburi landfill was made from 2014 to 2016, four times in the wet season and seven times in the dry season. Also, from the period 2015-2017, sampling and site investigation were conducted four times at Dangkor landfill (two in the wet and two in the dry season), and three field visits were made to the KM-32 landfill (one in the wet and two in the dry season). The sample names for this study are based on each site condition, as shown in Figure 1. Two types of leachate samples were collected for Nonthaburi landfill; one was the direct leachate (DL) sample taken from the leachate drain ditch along the toe of the waste pile in Area E, and the other was the leachate discharge pond (LDP) sample from the leachate discharge pond, beside Area E. At the Dangkor landfill, two types of fresh leachates were also sampled. Direct leachate from area B (DL.B) samples were collected from Areas A-B, which was closed in early 2016, and direct leachate from area C (DL.C) was collected from inside the active and deep pit of Area C. At the KM-32 landfill, direct leachate (DL) samples were collected from the dumped area, while wetland (WL) samples from the natural wetland, which is located at the lower part of the disposal facility. Additionally, the sediment samples were collected from the leachate sampling site, except at the sites where the leachate collected in the waste pile, i.e., DL.C at Dangkor, and DL in the KM-32 landfill. Figure 3 shows the physical visualization of the samples.

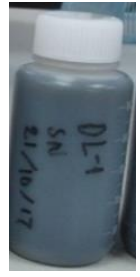

(a)

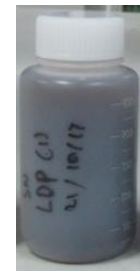

(b)

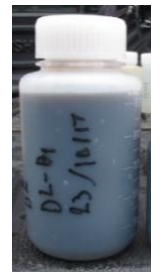

(c)

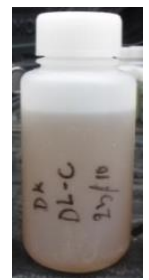

(d)

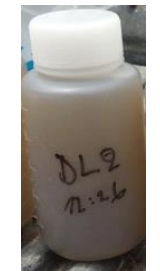

(e)

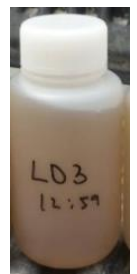

(f)

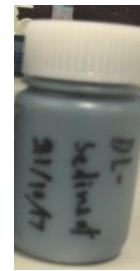

(g)

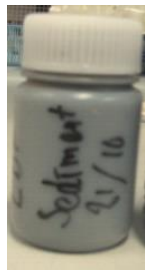

(h)

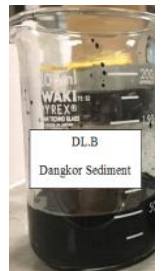

(i)

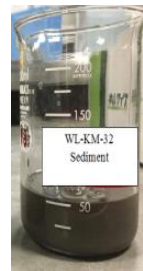

(j)

Figure 3. Leachate (a,b) Nonthaburi, DL and LDP; (c,d) Dangkor, DL.B and DL.C; (e,f) KM-32, DL and WL, and sediment (g,h) Nonthaburi, DL and LDP; (i) Dangkor, DL.B; (j) KM-32, WL.

\subsection{Measurements and Analysis}

\subsection{1. in-Situ Measurement}

In-situ water quality measurements were performed together with sample collection during the site visit and investigation. Some of the important basic parameters were measured at the site to assess the leachate quality such as Temp, $\mathrm{pH}$, oxidation-reduction potential (ORP), electrical conductivity (EC), turbidity (Turb), dissolved oxygen (DO), total dissolved solids (TDS), and Salt. The in-situ measurements were done by using the field toolkit "HORIBA-U50" (HORIBA, Ltd. Kyoto, Japan) for those mentioned parameters. At the same time, to confirm the sampling location, GPS photo tagger and Garmin Oregon were used in this study.

\subsubsection{Laboratory Measurement}

Preparation and Measurement of the Liquid Samples

All measurements are based on a standard method for water and wastewater examination for biochemical parameters such as biochemical oxygen demand $\left(\mathrm{BOD}_{5}\right)$, Chemical oxygen demand (COD), total Kjeldahl nitrogen (TKN) and so on. Heavy metals (HMs) were the main target for the assessment, aside from the mentioned basic parameters. The leachate samples were filtered using a syringe filter of $0.45 \mu \mathrm{m}$ pore size and then measured using ICP-AES (inductively coupled plasma-atomic emission spectrometry). The concentration of this filtered sample is dissolved HM concentrations in the liquid part of the leachate $\left(\mathrm{C}_{\mathrm{L}-\mathrm{LC}}\right)$. Besides, SALMATE $100 / \mathrm{W}$ was also used to measure the Chloride ion concentration for all samples. 
Preparation and Measurement of Unfiltered Leachate and Sediment Samples

To evaluate the heavy metals present in the unfiltered leachate samples and the sediment samples, acid digestion was applied in this study. In the method, $30 \mathrm{~mL}$ of $36 \% \mathrm{HF}$ (hydrofluoric acid) was used to digest the $0.20 \mathrm{~g}$ dry weight of the sediment or suspended solid, after the overnight oven-drying of the uniformly mixed sample for a certain amount at 105-110 C, and then the weight and volume were recorded. The digestion process was performed by stirring the mixing compound using a $50 \mathrm{~mL}$ PTFE (Polytetrafluoroethylene) beaker for approximately $24 \mathrm{~h}$ at $380 \mathrm{rpm}$ without heating. The solution was then filtered using a disposable syringe filter of $0.45 \mu \mathrm{m}$ pore size and analyzed by ICP-AES as the final stage for heavy metal concentration measurement. From the digested sample, the heavy metal concentration of the leachate can be obtained, which is the sum of the HMs dissolved in the liquid part and adsorbed in suspended solids (SS), defined as the total $\mathrm{HM}$ concentration of leachate $\left(\mathrm{C}_{\mathrm{T}_{-} \mathrm{LC}}\right)$ in this study. The leftover solid was partly used for organic content testing by using the ignition loss method of American Society for Testing and Materials (ASTM) D2974-87 (Method D) [33].

\section{Results and Discussions}

\subsection{Leachate Characterization}

\subsubsection{Basic and Biological Parameters}

Table 2 shows the summary of the in-situ and laboratory measurements for essential biological and chemical parameters, which are presented in the range (max-min) and the average for the samples collected in the wet and dry seasons. The effluent standards of the three countries are also indicated in the table. At the three sites, the wet (rainy) season starts from May or June, and ends in November or December. Besides $\mathrm{pH}$ and temperature, most of the parameters including oxidation-reduction potential (ORP), turbidity (Turb), electrical conductivity (EC) and the total dissolved solids (TDS) were found to be higher during the dry season than the wet season, especially for the Dangkor and KM-32 landfills. This is mostly due to dilution by rainwater. However, the waste fire in Area $\mathrm{C}$ of the Dangkor landfill that occurred before the sampling in the wet season of October 2016 could have caused the large difference. Similar variations in ORP, Turb, EC, and TDS were reported by some previous studies [34-43]. Chemical oxygen demand (COD) and biochemical oxygen demand $\left(\mathrm{BOD}_{5}\right)$ were found to be very much higher than the effluent standard limit of Thailand [44], which is similar to Cambodia, Laos, and Japan [45-47]. The $\mathrm{BOD}_{5}$ and $\mathrm{COD}$ were high concentrations for most samples, but slightly lower for the KM-32 landfill compared to the others. The high concentrations found in the Nonthaburi DL and Dangkor DL.B samples are partly attributed to soil cover, which could prevent water percolation into the waste to some extent. This range of COD indicated that the landfills were in the methanogenic phase [48]. Also, no significant seasonal changes were observed in the LDP of Nonthaburi landfill compared to the fresh leachate (DL sample), which could be partially attributed to the buffer effect of the huge leachate pond. 
Table 2. Basic biological parameters of leachate samples.

\begin{tabular}{|c|c|c|c|c|c|c|c|c|c|c|c|c|c|c|c|c|c|c|c|c|}
\hline \multirow{3}{*}{ Parameter } & \multirow{3}{*}{ Sea-Son } & \multicolumn{6}{|c|}{ Nonthaburi Landfill } & \multicolumn{6}{|c|}{ Dangkor Landfill } & \multicolumn{6}{|c|}{ KM-32 Landfill } & \multirow{3}{*}{$\begin{array}{l}\text { Effluent } \\
\text { Standard }\end{array}$} \\
\hline & & \multicolumn{3}{|c|}{ DL } & \multicolumn{3}{|c|}{ LDP } & \multicolumn{3}{|c|}{ DL.B } & \multicolumn{3}{|c|}{ DL.C } & \multicolumn{3}{|c|}{ DL } & \multicolumn{3}{|c|}{$W L^{s}$} & \\
\hline & & $\operatorname{Max}$ & Min & Ave & $\operatorname{Max}$ & Min & Ave & Max & Min & Ave & Max & Min & Ave & Max & Min & Ave & Max & Min & Ave & \\
\hline \multirow{2}{*}{ Temp $\left({ }^{\circ} \mathrm{C}\right)$} & Dry & 37 & 33 & 35 & 35 & 31 & 34 & 38 & 29 & 33 & 38 & 35 & 36 & 33 & 28 & 30 & - & - & - & \multirow{2}{*}{$\begin{array}{c}40[43] ; 45 \\
{[44]}\end{array}$} \\
\hline & Wet & 35 & 32 & 33 & 35 & 31 & 33 & 36 & 25 & 31 & - & - & $33 \#$ & 33 & 30 & 31 & 33 & 31 & 31 & \\
\hline \multirow{2}{*}{$\mathrm{pH}$} & Dry & 8.0 & 7.5 & 7.8 & 8.2 & 7.4 & 7.8 & 8.2 & 8.1 & 8.1 & 7.6 & 7.3 & 7.5 & 7.9 & 7.07 & 7.6 & - & - & & \multirow{2}{*}{$\begin{array}{l}5.5-9[43] \\
5-9[44] ; \\
6-9.5[45]\end{array}$} \\
\hline & Wet & 7.6 & 7.3 & 7.5 & 8.1 & 7.0 & 7.8 & 8.3 & 7.9 & 8.1 & - & - & 7.90\# & 7.9 & 7.0 & 7.5 & 8.2 & 8 & 8.03 & \\
\hline \multirow{2}{*}{$\mathrm{ORP}(\mathrm{mV})$} & Dry & -300 & -380 & -340 & 190 & -23 & 100 & -70 & -350 & -210 & -120 & -280 & -200 & -10 & -160 & -100 & - & - & - & \multirow{2}{*}{$\mathrm{NA}$} \\
\hline & Wet & -260 & -400 & -310 & 200 & -1 & 100 & -40 & -30 & -35 & - & - & $80 \#$ & 70 & -250 & -90 & 80 & 60 & 70 & \\
\hline $\mathrm{EC}(\mathrm{mS} / \mathrm{cm})$ & Wet & 28.9 & 20.3 & 24.1 & 18.6 & 10.2 & 15.0 & 27 & 15 & 26 & - & - & $2.0 \#$ & 3.8 & 3.6 & 3.7 & 3.7 & 3.3 & 3.5 & $7.5[43]$ \\
\hline \multirow{2}{*}{ Turb (NTU) } & Dry & 1000 & 950 & 970 & 450 & 180 & 320 & 1000 & 470 & 730 & 870 & 170 & 520 & 1000 & 195 & 590 & - & - & - & \multirow{2}{*}{20 [43] } \\
\hline & Wet & 1000 & 700 & 800 & 440 & 100 & 270 & 600 & 550 & 570 & - & - & $220 \#$ & 1000 & 60 & 380 & 360 & 70 & 120 & \\
\hline \multirow{2}{*}{$\mathrm{DO}(\mathrm{mg} / \mathrm{L})$} & Dry & 6.0 & 5.8 & 5.9 & 8.2 & 7.0 & 7.8 & 6.2 & 3.3 & 4.7 & 8.6 & 7.3 & 7.9 & 11.9 & 6.0 & 9.2 & - & - & - & $>1[44]$ \\
\hline & Wet & 8.0 & 5.8 & 7.7 & 9.8 & 6.6 & 8.2 & 8.3 & 7.8 & 8.1 & - & - & $7.6 \#$ & 10.5 & 8.7 & 9.6 & 10.5 & 10.1 & 10.3 & $>1[44]$ \\
\hline TDS (mo & Dry & 23,500 & 19,700 & 21,700 & 18,500 & 10,400 & 13,000 & 24,800 & 11,500 & 20,700 & 13,500 & 2200 & 6000 & 7000 & 2000 & 4900 & - & - & - & 3000 [43] \\
\hline IDS (ing/ L) & Wet & 17,900 & 6800 & 13,500 & 11,500 & 6300 & 9300 & 22,900 & 8150 & 15,000 & - & - & $1200 \#$ & 2500 & 2300 & 2400 & 2300 & 1100 & 1800 & $\begin{array}{l}2000[44] \\
3500[45]\end{array}$ \\
\hline $\operatorname{coD}(\mathrm{m} \sigma / \mathrm{L})$ & Dry & 7750 & 2050 & 3380 & 2320 & 470 & 1500 & 7900 & 2540 & 2900 & NM & NM & NM & 1080 & 570 & 770 & - & - & - & 120 [43]; \\
\hline $\mathrm{BOD}_{5}(\mathrm{~m} \mathrm{c} / \mathrm{L})$ & Dry & 1060 & 410 & 760 & 780 & 350 & 230 & NM & NM & NM & $\mathrm{NM}$ & NM & NM & 200 & 120 & 170 & - & - & - & 20 [43]; \\
\hline DUD5 (ling/L) & Wet & 1230 & 530 & 750 & 560 & 130 & 320 & $\mathrm{NM}$ & NM & NM & NM & NM & NM & 180 & 120 & 150 & 280 & 50 & 170 & $\begin{array}{l}80[44] ; \\
40[45]\end{array}$ \\
\hline NO $(\mathrm{mor})$ & Dry & - & - & $19 \#$ & NM & NM & NM & - & - & $0.9 \#$ & NM & NM & NM & $\mathrm{NM}$ & NM & NM & - & - & - & 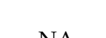 \\
\hline $\mathrm{NO}_{2}($ (III) $\mathrm{L})$ & Wet & - & - & 2\# & 210 & 13 & 112 & - & - & $<0.5$ & - & - & $21 \#$ & - & - & $48 \#$ & - & - & $22 \#$ & NA \\
\hline $\mathrm{NO}_{3}(\mathrm{mg} / \mathrm{L})$ & Dry & - & - & 2\# & $\mathrm{NM}$ & $\mathrm{NM}$ & $\mathrm{NM}$ & $\mathrm{NM}$ & NM & NM & NM & NM & NM & $\mathrm{NM}$ & NM & NM & - & - & - & $20[44]$ \\
\hline & Wet & 1.9 & 0.4 & 1.2 & 29 & 3.3 & 13.9 & - & - & $2 \#$ & - & - & $3.4 \#$ & - & - & $11 \#$ & - & - & $\begin{array}{l}3.2 \\
\#\end{array}$ & \\
\hline $\mathrm{NH}_{3}(\mathrm{mg} / \mathrm{L})$ & Dry & 2350 & 270 & 1060 & 210 & 110 & 150 & - & - & $920 \#$ & NM & NM & NM & NM & NM & NM & - & - & - & \\
\hline 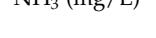 & Wet & 1970 & 560 & 1150 & 200 & 110 & 150 & - & - & 780 \# & - & - & $26 \#$ & - & - & 100 \# & - & - & $50 \#$ & 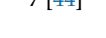 \\
\hline TKN (mg/L) & Dry & 1570 & 360 & 1190 & 360 & 240 & 290 & $\mathrm{NM}$ & NM & NM & $\mathrm{NM}$ & NM & $\mathrm{NM}$ & $\mathrm{NM}$ & $\mathrm{NM}$ & NM & - & - & - & $100[43]$ \\
\hline & Wet & 7910 & 1150 & 3030 & 260 & 210 & 250 & $\mathrm{NM}$ & NM & NM & NM & NM & NM & $\mathrm{NM}$ & $\mathrm{NM}$ & NM & NM & NM & $\mathrm{NM}$ & \\
\hline $\mathrm{Cl}(\mathrm{m} \sigma / \mathrm{L})$ & Dry & 4970 & 3370 & 4410 & 5750 & 4380 & 5050 & 4260 & 2250 & 3250 & - & - & $2050 \#$ & 1,200 & 290 & 650 & - & - & - & \\
\hline & Wet & 4510 & 3130 & 3630 & 5300 & 3770 & 4450 & - & - & $2730 \#$ & - & - & $290 \#$ & 390 & 330 & 360 & 370 & 340 & 350 & 5] \\
\hline
\end{tabular}

NA: Not Available; NM: Not Measured; ${ }^{\$}$ : No water in WL of K32 in the dry season; \#: Only one sample; DL: direct leachate; LDP: leachate discharge pond; DL.B: direct leachate from area

B ; DL.C: direct leachate from area C; DL: direct leachate; WL: wetland. 
There have been associated results to this study, as reported in previous studies for other landfills in other countries [34,35,38,48-52]. Nitrite $\left(\mathrm{NO}_{2}\right)$, nitrate $\left(\mathrm{NO}_{3}\right)$, and ammonia $\left(\mathrm{NH}_{3}\right)$ were measured for some samples from the sites. The ammonium concentrations showed very high value, particularly for the Nonthaburi DL and Dangkor DL.B samples. Although the data is limited, the higher nitrite and nitrate concentrations in the LDP samples than in the DL samples at the Nonthaburi site could indicate the nitrification of the LDP with an oxidation environment, which is confirmed by the ORP values. The total Kjeldahl nitrogen (TKN) was measured only for the samples from the Nonthaburi site, which also showed significant differences between fresh leachates (DL) and those stored in the LDP; these were higher for the DL than the LDP. Compared to the standard, very high chloride $(\mathrm{Cl})$ concentrations were observed for the Nonthaburi sites and the Dangkor DL.B, ranging from 3000-5000 mg/L. Tanchuling et al. (2015) conducted a similar study on a landfill in the Philippines and also reported a high chloride concentration in the leachate, ranging 2400-3500 mg/L [53]. They found relatively high chloride concentrations in the shallow wells near the landfill and discussed the possibility of chloride as a tracer for the investigation of groundwater contamination by the landfill, which could be applicable for the study sites with high $\mathrm{Cl}$ concentrations in the leachates.

Figure 4a shows the relationship between $\mathrm{Cl}$ and TDS concentration. Although the ranges of concentrations were quite different for Nonthaburi DL and Dangkor DL.B compared to KM-32 and Dangkor DL.C, a positive correlation can be seen in the relationship for all the data from the three landfills. $\mathrm{Cl}$ concentrations of LDP were relatively higher than those of the DL samples, which implies the accumulation of $\mathrm{Cl}$ in the storage pond as a conservative chemical. The relationship between $\mathrm{BOD}_{5}$ and COD measured for the samples of Nonthaburi and KM-32 (Figure $4 \mathrm{~b}$ ) shows a positive correlation, and there was higher $\mathrm{BOD}_{5}$ and $\mathrm{COD}$ in Nonthaburi than in the KM-32 landfill. The low organic contents of the KM-32 landfill could be attributed to the high waste wash rate for the open dumping practice, which does not use cover soils and which has a shallow waste depth, compared to the Nonthaburi landfill. The $\mathrm{BOD}_{5} / \mathrm{COD}$ ratios of the DL samples ranged from 0.1 to 0.6 for the two landfills. The relatively low $\mathrm{BOD}_{5} / \mathrm{COD}$ ratio of the $\mathrm{LDP}$ and $\mathrm{WL}$ sample could indicate that biological decomposition is taking place in the storage ponds. Similar results to those discussed above were found by previous studies of other landfills $[35,38,50-52,54]$.

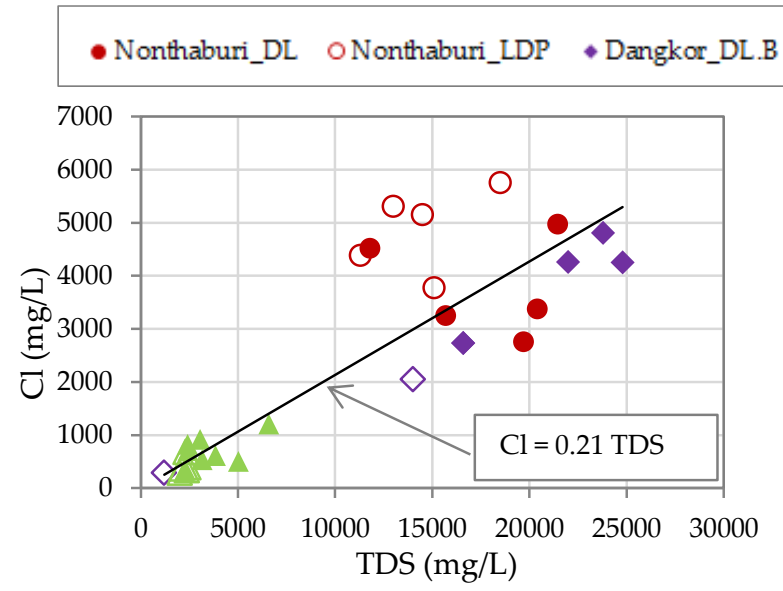

(a)

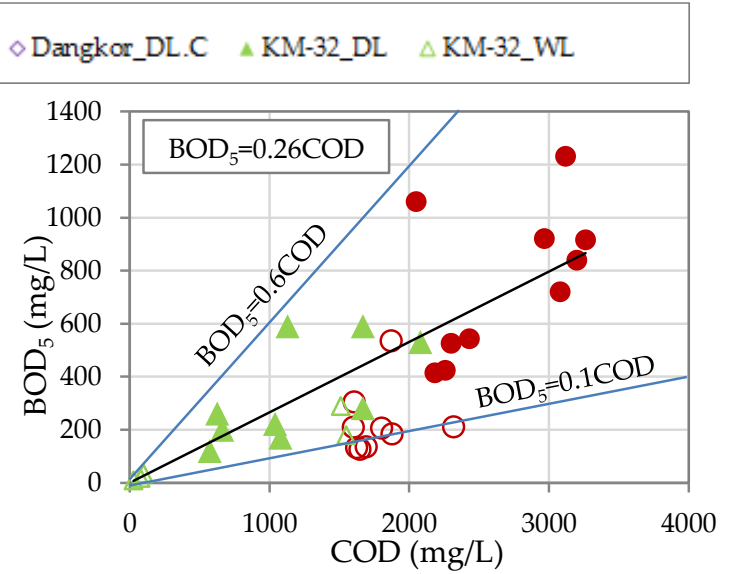

(b)

Figure 4. (a) Relationship between $\mathrm{Cl}$ and TDS; (b) Relationship between $\mathrm{BOD}_{5}$ and $\mathrm{COD}$.

Figure 5a shows the relationship between COD and TDS for the leachates in this study. Although COD includes the organics in the suspended solids, there is relatively good correlation if all the data from the three sites are compared. However, specific differences can be seen between different sites and different types of leachate. For example, the COD/TDS ratios of the Nonthaburi LDP samples were smaller than the DL and almost no correlation can be seen for the data from KM-32. This 
relatively small COD for the LDP could be due to the sedimentation of organic materials under the still conditions in the huge pond. Figure $5 \mathrm{~b}$ shows the relationship between the COD and suspended solids concentration ( $\left.\mathrm{C}_{\mathrm{SS}}\right)$. Although the measured points are limited, good correlation can be confirmed. From the regression line shown in the figure, it can be inferred that SS is the major source of organics in the leachate.

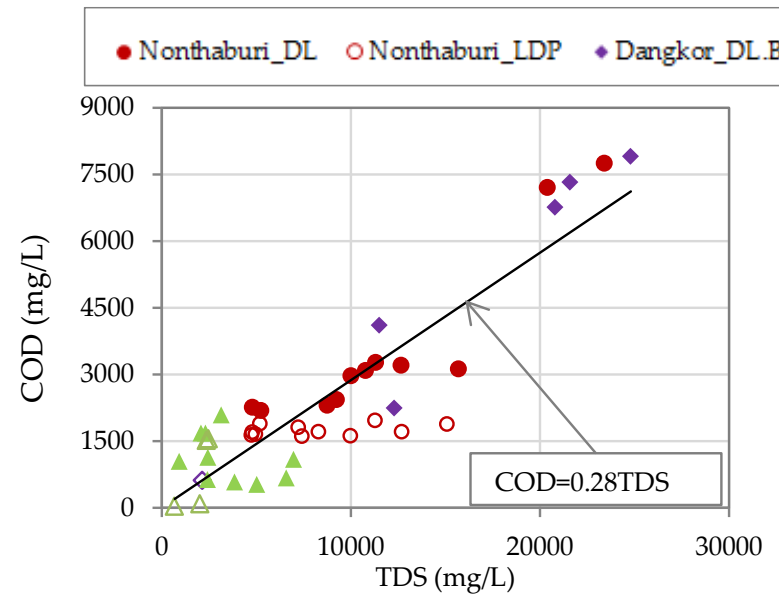

(a)

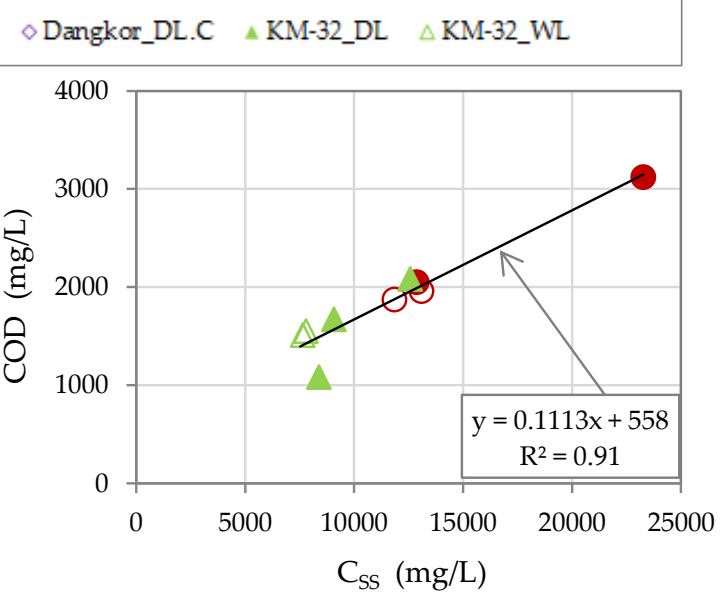

(b)

Figure 5. (a) Relationship between COD and TDS; (b) Relationship between COD and suspended solids concentration $\left(\mathrm{C}_{\mathrm{SS}}\right)$.

\subsubsection{Suspended Solids Composition of Leachate}

The leachate samples as a contaminant source were separated into two parts. One was the liquid part (Liq), which accounted for the main part of the leachate, and the other was the suspended solids (SS) or solid part, which was usually a small fraction of the leachate. The amount of SS depends on the leachate quality, which is related to waste composition, age, precipitation and the location where the leachate is stored, e.g., drainage canal, storage pond. Figure 6a shows the relationship between the SS concentration $\left(\mathrm{C}_{\mathrm{SS}}\right)$ and solid concentration $\left(\mathrm{C}_{\text {solid }}\right)$ with positive increasing trends. The suspended solids concentration of the leachates ranged from $7500-23,300 \mathrm{mg} / \mathrm{L}$, while the solid concentration was as high as $43,000 \mathrm{mg} / \mathrm{L}$, about two times higher than $\mathrm{C}_{\mathrm{SS}}$. As depicted in Figure $6 \mathrm{~b}$, the organic concentration of the leachate $\left(\mathrm{C}_{\mathrm{org}}\right)$ also shows a positive relationship with $\mathrm{C}_{\mathrm{SS}}$. The organic content contained in the leachate samples ranged from $1600-8200 \mathrm{mg} / \mathrm{L}$. Although the particle size of the SS was not measured, the high percentage of fine particles could be expected, and came from the clay materials used as covering soil, which is shown in a later section. The Nonthaburi leachates contained a relatively high SS concentration, while the KM-32 landfill leachates had the lowest. As for the different types of leachate at each site, the similar differences to the basic parameters discussed in the previous section confirmed that the DL samples contained a higher amount of solids and SS than the LDP and wetland for the Nonthaburi and KM-32 landfill, respectively. For the Dangkor landfill, the leachate samples collected from the closed area (DL.B) were considerably higher than the ongoing dumping area (DL.C), especially for the organic content. This is mostly attributed to the waste fire that broke out in the early stage of Area C, as discussed in the previous section. However, in the DL.C sample, the rate of organics increased rapidly from $1800 \mathrm{mg} / \mathrm{L}$ to $5200 \mathrm{mg} / \mathrm{L}$ in November (2016) and March (2017). This was due to the rapid increase of garbage volume inside Area C, and no more fires occurred, as before. In addition, the seasonal variations of $C_{\text {solid }}, C_{S S}$ and $C_{\text {org }}$ for all samples at all the sites were confirmed as having a higher concentration in the dry season than the wet season. 


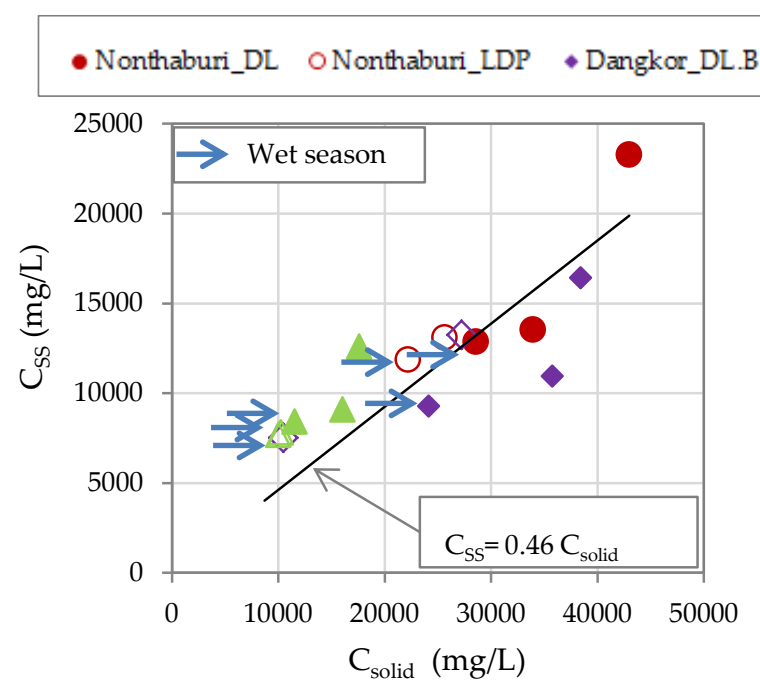

(a)

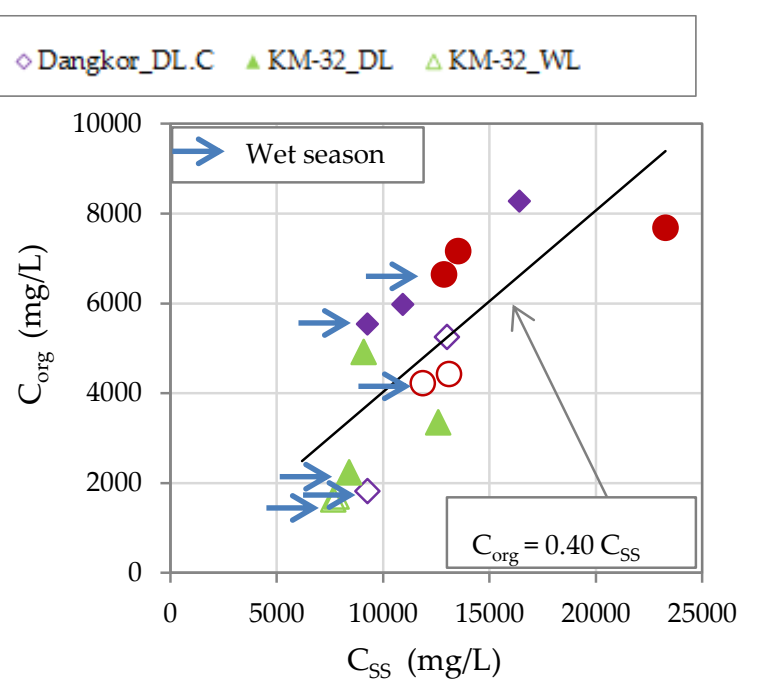

(b)

Figure 6. (a) Relationship of SS concentration ( $\left.\mathrm{C}_{\mathrm{SS}}\right)$ and total solid concentration $\left(\mathrm{C}_{\text {solid }}\right)$ of the leachate;

(b) Relationship of organic content ( $\left.\mathrm{C}_{\text {org }}\right)$ and SS concentration $\left(\mathrm{C}_{\mathrm{SS}}\right)$.

\subsubsection{Dissolved Heavy Metals in Liquid Part of Leachate}

Figure 7a-c show the dissolved heavy metal (HM) concentrations in the liquid part of the leachates $\left(\mathrm{C}_{\mathrm{L}-\mathrm{LC}}\right)$ sampled at the three landfills. Five harmful HMs-arsenic $(\mathrm{As})$, lead $(\mathrm{Pb})$, cadmium $(\mathrm{Cd})$, chromium ( $\mathrm{Cr}$ ) and zinc $(\mathrm{Zn})$ - were measured. These HMs have commonly been found for most leachates in past and current studies. The average values for the dry and wet seasons were also shown in the figures. The average of the measured HM concentrations of the fresh leachate (DL) from the three landfills, excluding the Dangkor DL.C samples, are compared in Figure 7d. The industrial effluent and groundwater standards of Thailand [44] are also indicated in the figures as the references. Regarding the effects of the sites and seasonal conditions on HMs, similar trends can be pointed out as discussed in the basic parameters in Table 2. In particular, the fresh leachate samples (DL) had higher concentrations than those found in the LDP and WL at the Nonthaburi and KM-32 landfill. As for the Dangkor landfill, the HM concentrations of the DL.B samples from the closed and covered area were larger than the DL.C samples taken from the ongoing deep pit landfill. The higher concentration during the dry season compared to the wet season was also confirmed, but less significant seasonable differences can be seen for the LDP samples than the DL samples at the Nonthaburi landfill, and for the DL.B samples than the DL.C samples at the Dangkor landfill, respectively. The magnitude order of the HM concentrations is quite similar at the three landfills. The highest and lowest were $\mathrm{Zn}$ and $\mathrm{Cd}$, respectively, and the other $\mathrm{HMs}$ were in the order $\mathrm{Cr}, \mathrm{As}$ and $\mathrm{Pb}$. The concentrations of fresh leachates were the highest for the Nonthaburi landfill and the lowest for the KM-32 landfill. The Dangkor DL.C samples had similarly small concentration to those of the KM-32 DL samples.

Besides the HM contents in the disposed residue, several reasons can be considered for the concentration differences between the sites, and the types of leachate at each site. The volume of water percolating over the unit volume of waste could be one of the major controlling factors for the HM concentrations. The KM-32 landfill has a wider opened space and thinner waste layer compared to the other landfills, and no soil cover had been provided until the time of the sampling, which is similar to the conditions in Dangkor Area C. The redox condition of the disposed waste and leachate also affects the HM solubility and concentration [51,54]. Waste segregation was not fully applied in these landfills. Therefore, the presence of high $\mathrm{Cr}$ in the leachate samples was due to the presence in the waste mixture of $\mathrm{Pb}-\mathrm{Cr}$ batteries, colored polyethylene bags, discarded plastic materials and empty paint containers $[42,55]$. The high concentration of $\mathrm{Zn}$ in the leachates could be attributed to the 
disposal of batteries, fluorescent lamps, food waste and burning tires at the site $[17,56]$. However, the effects of $\mathrm{pH}$ and ORP could not be confirmed by the measurements in this study.
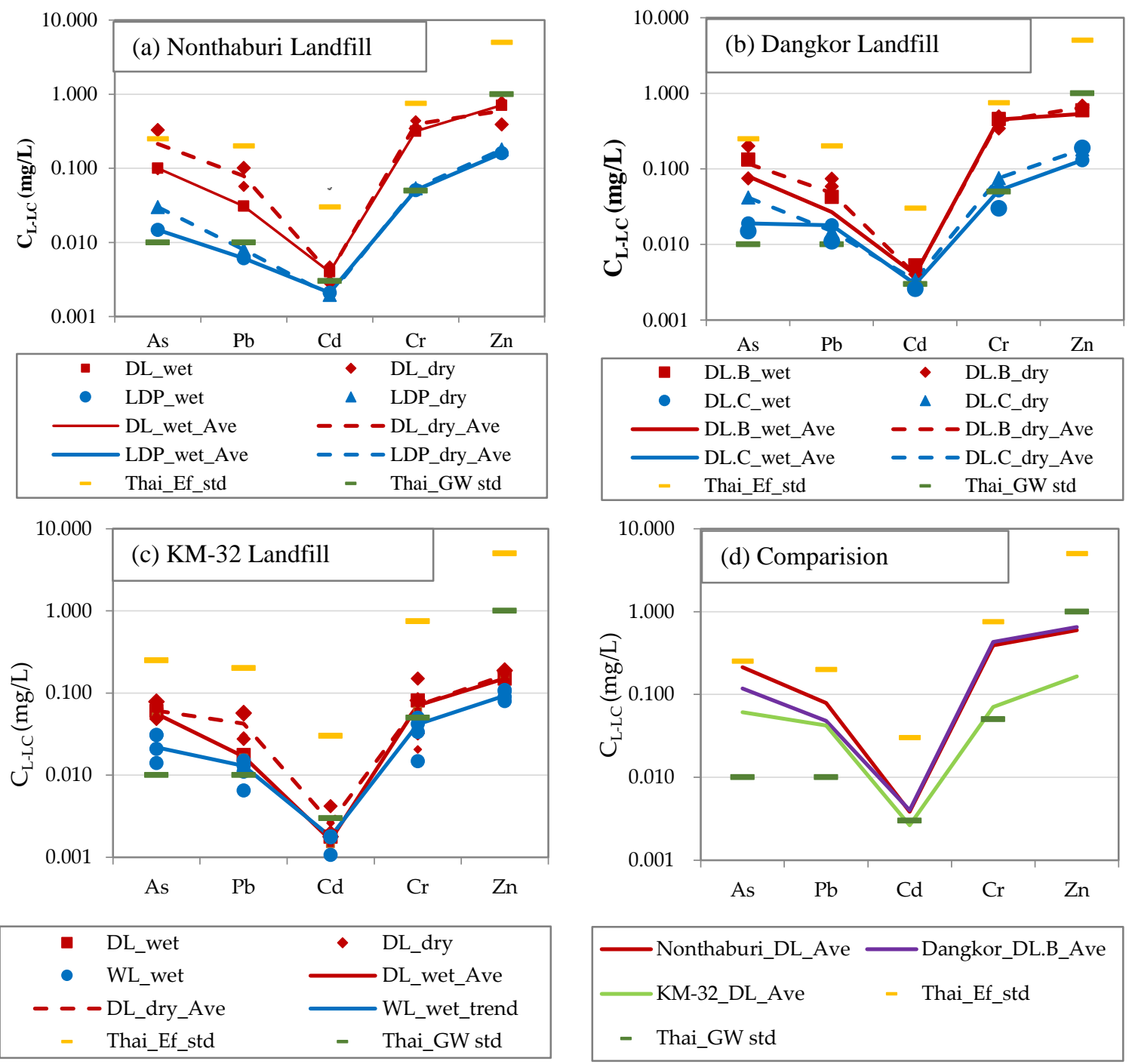

Figure 7. Heavy metal concentration of the liquid part of the leachate samples $\left(\mathrm{C}_{\mathrm{L}-\mathrm{LC}}\right)$ : $(\mathbf{a})$ Nonthaburi landfill; (b) Dangkor Landfill; (c) KM-32 landfill; and (d) Average heavy metal concentration in the liquid part of the leachate $\left(\mathrm{C}_{\mathrm{L}-\mathrm{LC}}\right)$.

The maximum concentrations of all the HMs were more than the groundwater standard (GW std) [44], and even close to or above the effluent standards, and the average concentrations were all over the groundwater environmental standard, with the exception of $\mathrm{Zn}$. Although the low permeability of the geological barrier has protected the groundwater, such high concentrations in the liquid part of the leachate could be a potential risk of groundwater contamination in the surrounding area in the future, especially for the Dangkor landfill, which has dump pits with a significant depth of about $30 \mathrm{~m}$ from the ground surface of the ongoing landfill in areas $C$ and $D$.

\subsubsection{Total Heavy Metal Concentration of Leachate}

As explained in Section 2.4.2, the total HM concentration of the leachate $\left(\mathrm{C}_{\mathrm{T}-\mathrm{LC}}\right)$ was also measured for the same HMs discussed in the previous section ( $\mathrm{As}, \mathrm{Pb}, \mathrm{Cd}, \mathrm{Cr}$ and $\mathrm{Zn}$ ). The total HM concentration is presented in Figure 8 for the wet and dry seasons, together with the dissolved HM concentration of the liquid part of the leachate $\left(\mathrm{C}_{\mathrm{L}-\mathrm{LC}}\right)$. Thai industrial effluent and groundwater standards are 
also indicated in the figure. Similar trends of seasonal variation for both $\mathrm{C}_{\mathrm{T}-\mathrm{LC}}$ and $\mathrm{C}_{\mathrm{L}-\mathrm{LC}}$ could be confirmed, namely with higher values for the dry season and lower values for the wet season. The most significant point confirmed from the figure is the large difference between the liquid part and the total concentration, about 2-20,3-30, 17-50, 2-10 and 2-7 times larger for the latter than the former for $\mathrm{As}, \mathrm{Pb}, \mathrm{Cd}, \mathrm{Cr}$ and $\mathrm{Zn}$, respectively. The total $\mathrm{HM}$ concentrations are at significant levels, especially for $\mathrm{Cd}, \mathrm{Pb}$, and $\mathrm{As}$, which are more than a few times greater than the effluent standard. A leachate treatment facility has not been implemented in these landfills, and uncontrolled discharge or leakage of leachate often happens. Under such conditions, leachate with such high HM concentrations could be a source of surface water contamination and soil contamination of surrounding water bodies and agricultural fields.

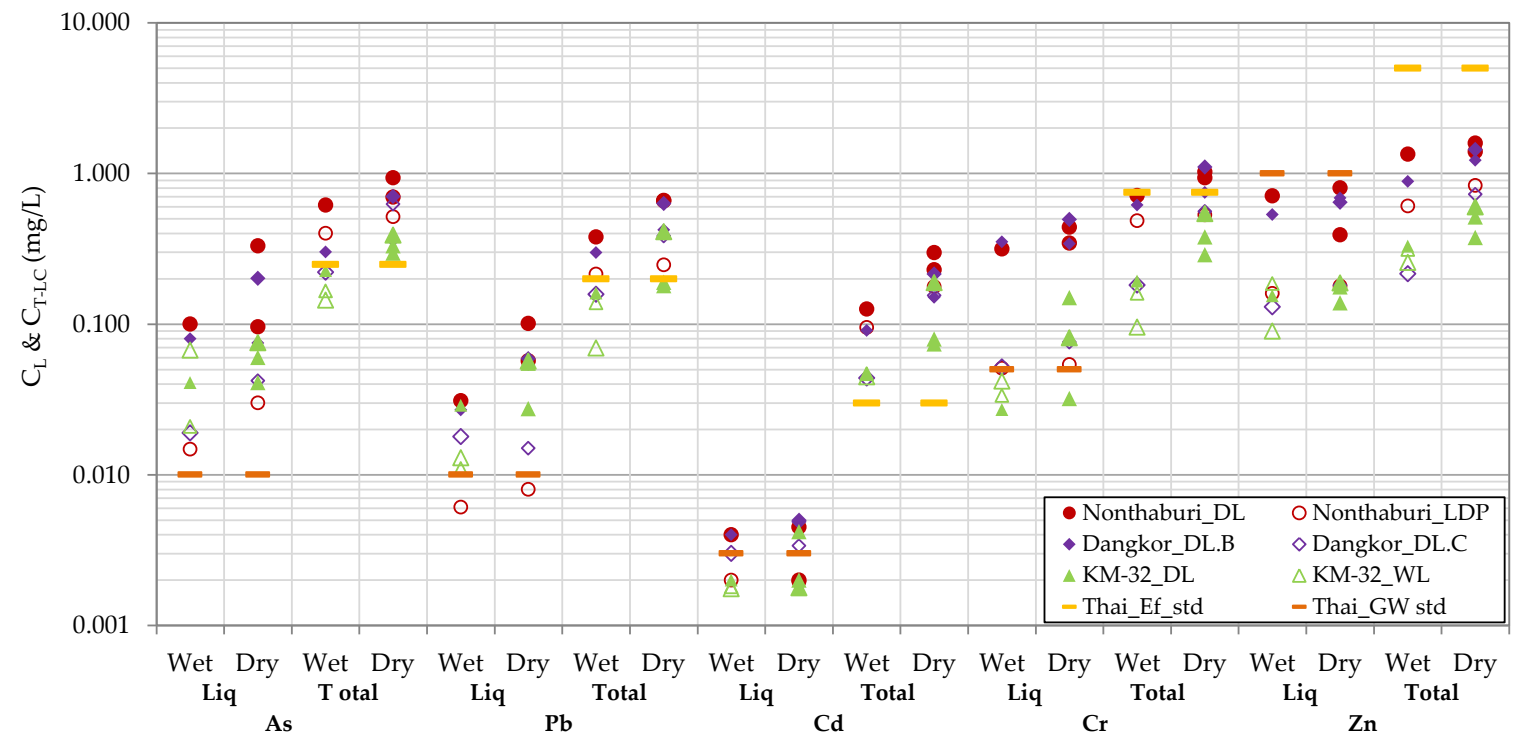

Figure 8. Heavy metal concentrations of the total (Total) and liquid part (Liq) of the leachate.

The relationship between the total HM concentration ( $\left.\mathrm{C}_{\mathrm{T}-\mathrm{LC}}\right)$ and SS concentration $\left(\mathrm{C}_{\mathrm{SS}}\right)$ of leachates is presented in Figure 9. A relatively good linear correlation can be seen for arsenic, while the other HMs show some positive relationships, but not high correlation. However, the correlation is higher for the separated data for each site than the combined data for all the landfills, especially for the Dangkor landfill. The properties of the leachates depend on the various conditions at each site, e.g., soil cover, active or inactive, and the composition of the SS. The difference in the SS components can be confirmed by the level of leachate appearance, and the clear, dark, brown or pink color of the leachate at different landfill sites and locations (Figure 1). Another factor is the difference in the portion of metal in the solid waste, which is a primary source of the HM concentrations presented in Figure 2. 

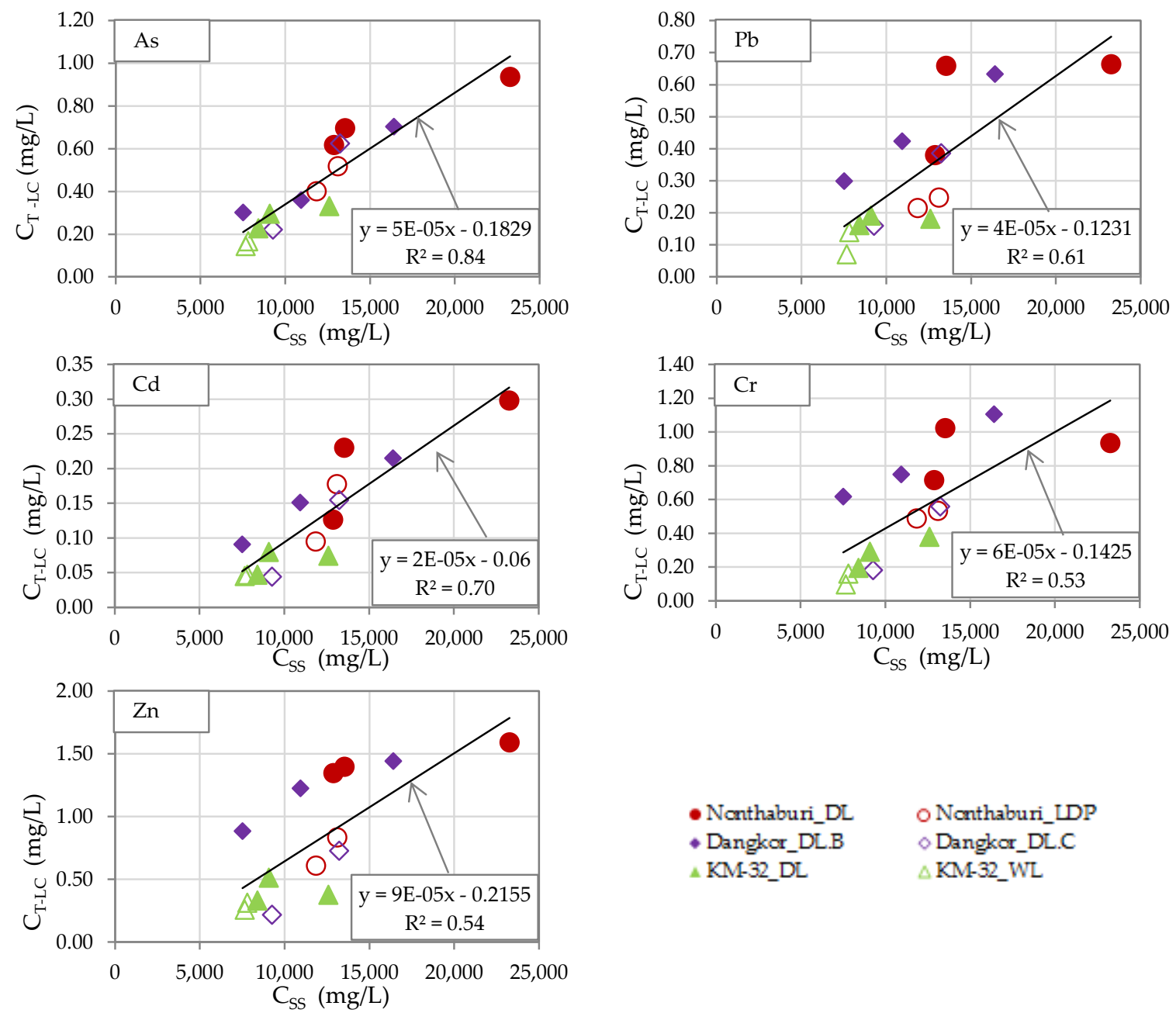

Figure 9. Relationship of total heavy metal concentration of the leachate $\left(\mathrm{C}_{\mathrm{T}-\mathrm{LC}}\right)$ and the suspended solid concentration ( $\left.\mathrm{C}_{\mathrm{SS}}\right)$.

\subsubsection{Heavy Metal Contents of Suspended Solids}

Figure 10 shows the HM contents in the unit mass of SS ( $\left.\mathrm{C}_{\mathrm{S}-\mathrm{SS}}\right)$ and SS concentration $\left(\mathrm{C}_{\mathrm{ss}}\right)$. The HM contents were calculated using the SS concentration of the total and of the liquid part of the leachate samples. As seen in the figure, although the SS concentration of the leachate was higher in the dry season than in the wet season, no clear seasonal differences can be seen for $\mathrm{C}_{\mathrm{S}-\mathrm{SS}}$ in all the landfills. The magnitude order of the $\mathrm{C}_{\mathrm{S}-\mathrm{SS}}$ in this set of HMs is Nonthaburi $>$ Dangkor $>\mathrm{KM}-32$ landfill. This order is confirmed for the total concentration $\left(C_{T-L C}\right)$ in Figure 8 . The magnitude order of the $C_{\mathrm{L}-\mathrm{LC}}$ for the sites and the HMs could be attributed to the order of the $C_{S S}$ and $C_{S-S S}$. Both $C_{S S}$ and $C_{S-S S}$ are affected by the properties of SS, especially organic content and fine particle content. The higher these contents, the greater the suspension of the particles and the greater the partitioning of the HMs in the SS.

The HMs contained in the SS per unit volume of leachate $\left(\mathrm{C}_{\mathrm{SS}}{ }^{*} \mathrm{C}_{\mathrm{S}-\mathrm{SS}}\right)$ are plotted with the total $\mathrm{HM}$ concentrations $\left(\mathrm{C}_{\mathrm{T}-\mathrm{LC}}\right)$ in Figure 11 . The plots for $\mathrm{Pb}$ and $\mathrm{Cd}$ are very close to the 1:1 line, which means that the HM contents in the liquid part was very small and about $80-99 \%$ of the total contents were partitioned in the SS. As for As and Cr, the contents were also adsorbed in the SS by about $80-90 \%$, with some exceptions, but not less than $60 \%$. However, the $\mathrm{Zn}$ was less partitioned on the SS compared to the other metals, and some points showed less than $50 \%$. Elliott et al., reported that $\mathrm{Zn}$ had the lowest sorption capacity for the organic soils [57]. The SS in the leachates contained high 
organic content, similar to their sample condition. As a general trend, it can be said that the SS part contents became smaller as the total concentration increased, especially for As and $\mathrm{Cr}$.

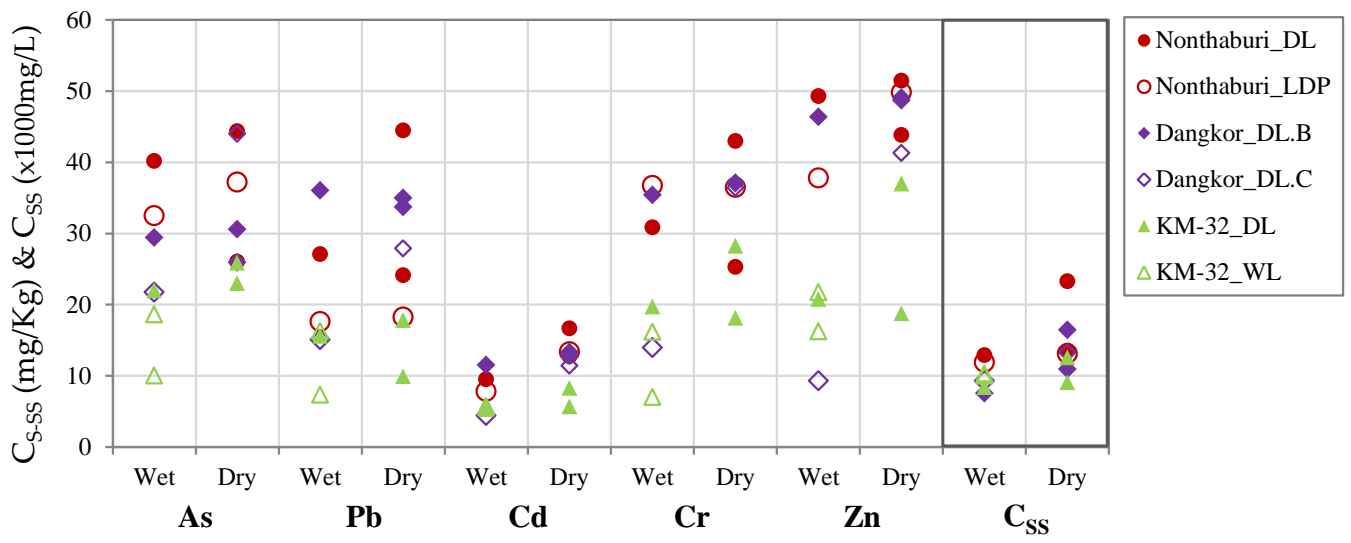

Figure 10. Heavy metal content of suspended solids $\left(\mathrm{C}_{\mathrm{S}^{-} \mathrm{SS}}\right)$ of leachate samples.
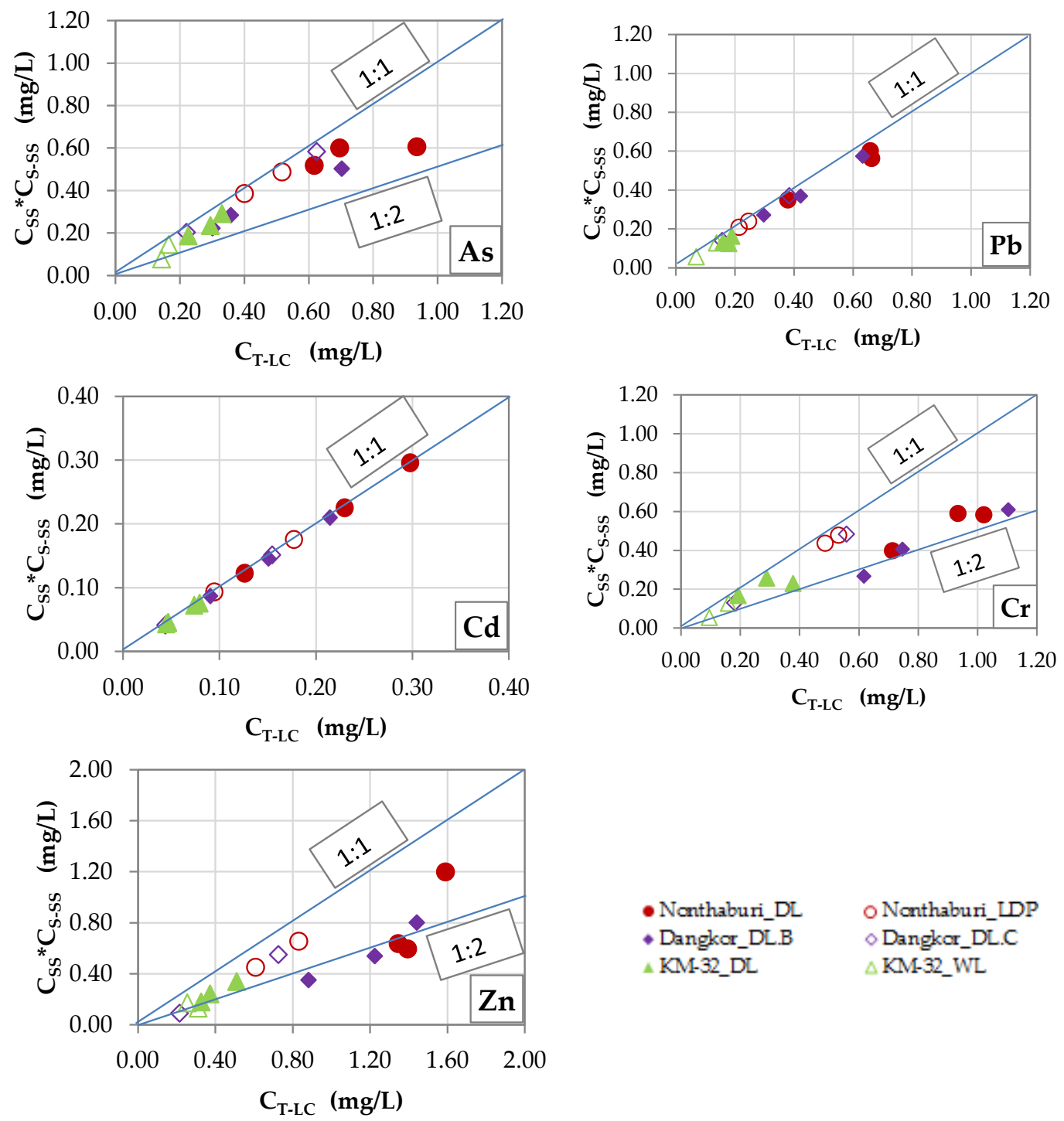

$\triangle$ KM-32_DL $\triangle$ KM-32_WL

Figure 11. Relationship of HM concentration adsorbed in the $S S\left(C_{S S}{ }^{*} C_{S-S S}\right)$ and total heavy metal concentration of Leachate $\left(\mathrm{C}_{\mathrm{T}-\mathrm{LC}}\right)$. 
As large portions of the harmful heavy metals $\mathrm{Pb}, \mathrm{Cd}$, As and $\mathrm{Cr}$ in the leachate are partitioned in the SS, simple physical filtration and sedimentation of the SS fraction from the leachate could significantly decrease the total HM concentration [58]. This is considered the easiest and cheapest manner of leachate treatment to reduce the potential environmental risk to the areas surrounding the landfills.

The relationships of the heavy metal contents in the SS ( $\left.\mathrm{C}_{\mathrm{S}-\mathrm{SS}}\right)$ and dissolved HM concentrations in the liquid part of the leachate $\left(\mathrm{C}_{\mathrm{L}-\mathrm{LC}}\right)$ are shown in Figure 12. They show some correlations but no clear relationship, as neither linear nor non-linear isotherms could be seen in the figures. This is due to the limited amount of data, and also to the difference in the composition of the SS. Furthermore, the sorption might not necessarily take place under the measured $C_{L-L C}$. Nonetheless, the data points could provide an apparent partitioning coefficient, $\mathrm{K}_{\mathrm{d}}\left(\sim \mathrm{C}_{\mathrm{S}-\mathrm{SS}} / \mathrm{C}_{\mathrm{L}-\mathrm{LC}}\right)$. The data points of $\mathrm{Cd}$ show the highest $\mathrm{K}_{\mathrm{d}}$, ranging $2000-5000 \mathrm{~L} / \mathrm{kg}$, which can be attributed to a very low liquid part concentration. However, not only for $\mathrm{Cd}$, but also the other $\mathrm{HMs}$, the $\mathrm{K}_{\mathrm{d}}$ values tend to be larger. The relationship of $\mathrm{Zn}$ somehow shows the maximum sorption capacity as the constant $\mathrm{C}_{\mathrm{S} \text {-SS }}$ values for the DL data from Nonthaburi landfill and the DL.B data from Dangkor landfill. This non-linear partitioning behavior could be a reason for the relatively low fraction of $\mathrm{Zn}$ in the SS in the leachate, and the trend towards part fractions of HMs in the SS to the total concentration, as presented in Figure 11. Despite this, As, $\mathrm{Cr}$ and $\mathrm{Pb}$ show a wide range of $\mathrm{K}_{\mathrm{d}}$, ranging about $100-2000 \mathrm{~L} / \mathrm{kg}$. From the relatively high $\mathrm{K}_{\mathrm{d}}$ values in the Nonthaburi LDP samples, it could be also inferred that the HMs were adsorbed in the suspended solids under relatively large $\mathrm{C}_{\mathrm{L}-\mathrm{LC}}$ before entering the leachate storage pond. It should be mentioned that the SS properties are not the only controlling factors, but that the HM contents in the waste composition is also a key factor in this matter. One of the pieces of evidence that should be pointed out is that the waste from the Nonthaburi landfill contains a higher amount of metal in its composition than the other landfills (Figure 2$)$, which could result in higher concentrations $\left(\mathrm{C}_{\mathrm{L}-\mathrm{LC}}\right.$ and $\mathrm{C}_{\mathrm{T}-\mathrm{LC}}$ ) of most of the elements than in the other landfills.

Organic content $\left(\mathrm{C}_{\mathrm{org}}\right)$ is also a key parameter affecting the heavy metal content present in the SS. Figure 13 shows the relationships between the HM contents of the SS and the organic contents of the leachate. Although some scatterings are observed, there are positive correlations between all the HMs and the organic content. The scattering is due to the differences of the leachate characteristics at the different sites, regarding the heavy metal concentration of the liquid part and other related sorption behaviors, such as the difference in adsorption capacity, reaction, and oxidation, as confirmed by a previous study [57].
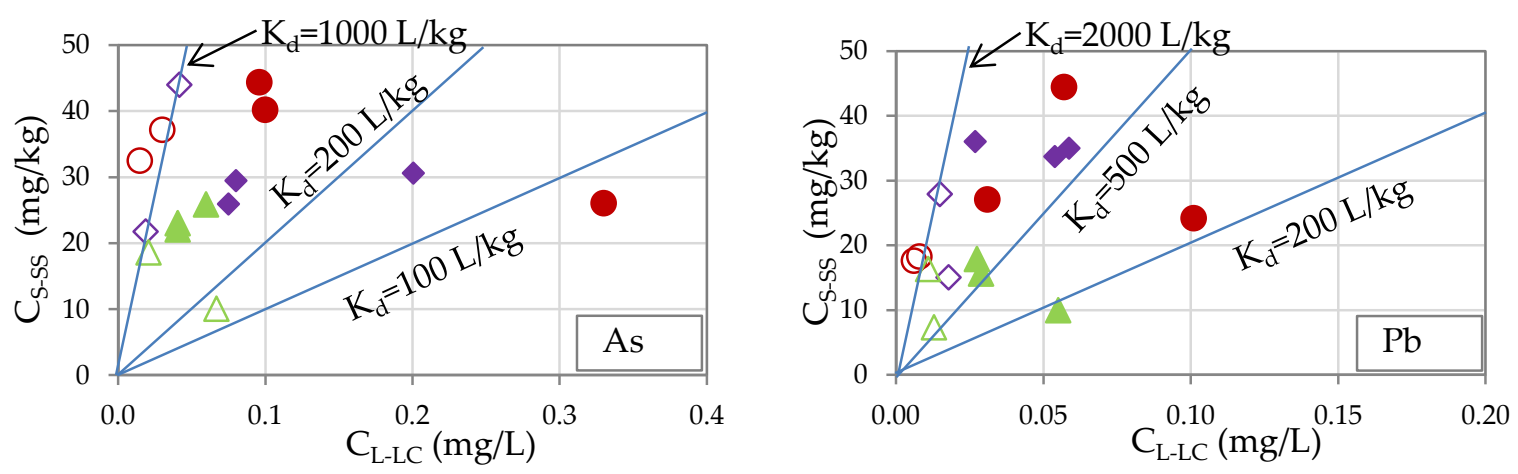

Figure 12. Cont. 

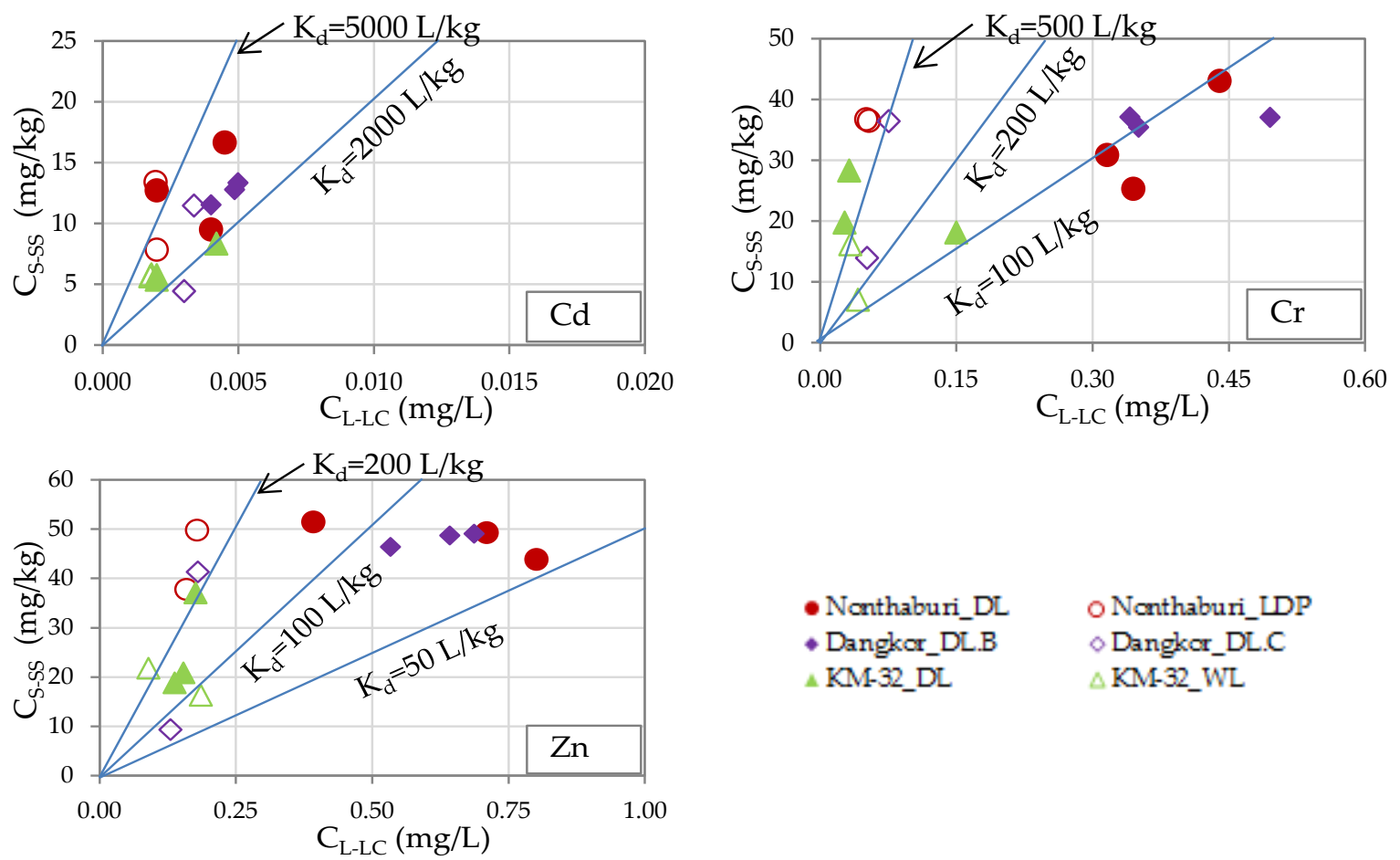

Figure 12. Relationship of the heavy metal content of suspended solids $\left(\mathrm{C}_{\mathrm{S}-\mathrm{SS}}\right)$ and the liquid part of the leachate $\left(\mathrm{C}_{\mathrm{L}-\mathrm{LC}}\right)$.
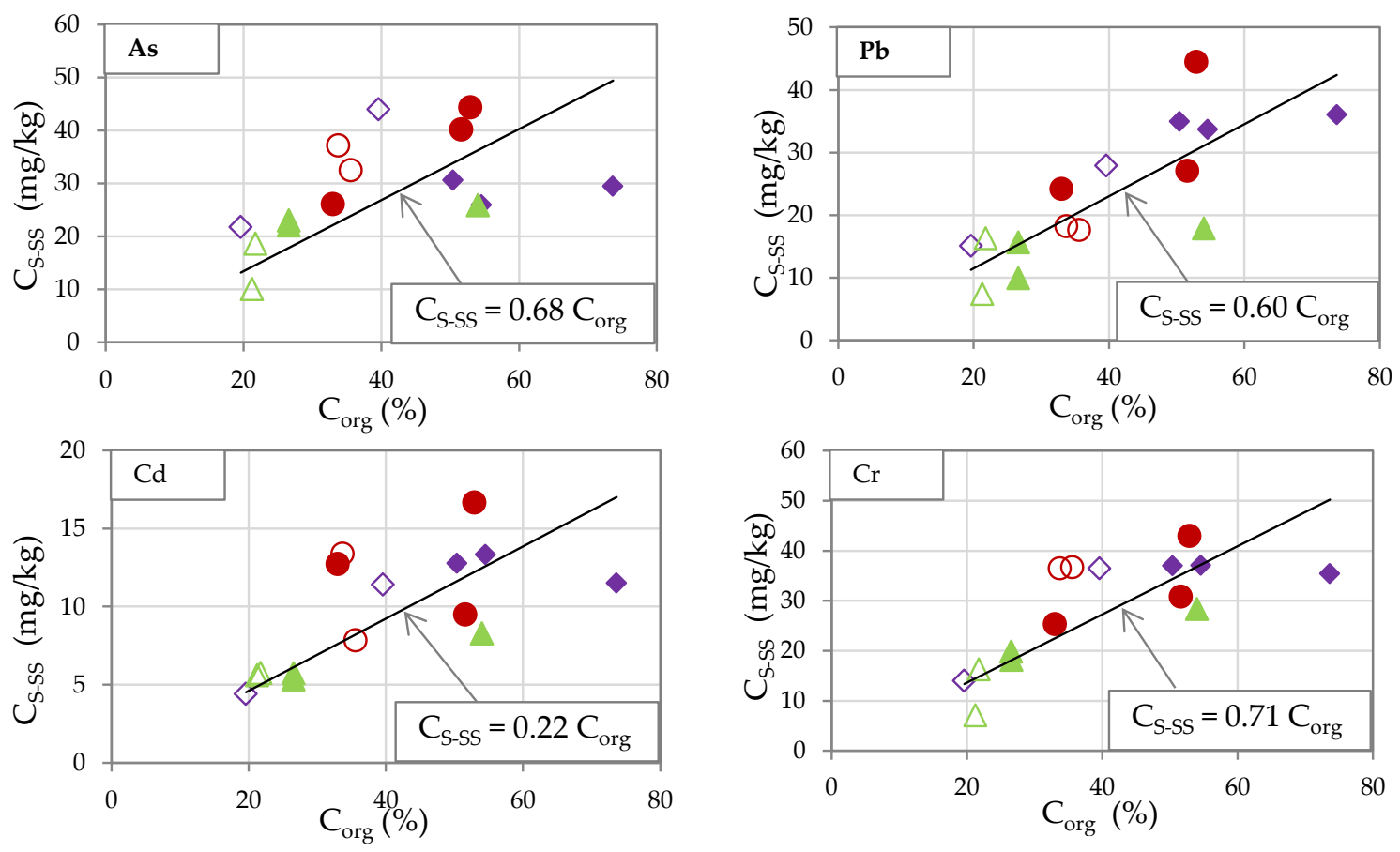

Figure 13. Cont. 


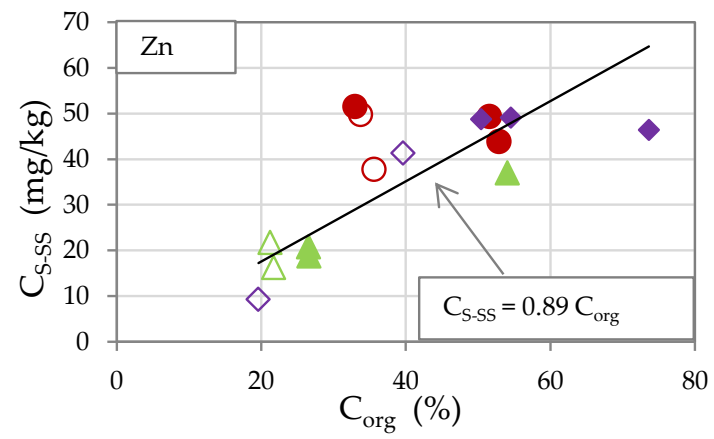

- Nonthaburi_DL

- Dangkor_DL.B

$\triangle$ KM-32_DL
O Nonthaburi_LDP

$\circ$ Dangkor_DL.C

$\triangle$ KM-32_WL

Figure 13. Relationship of the heavy metal concentration of the suspended solids ( $\left.\mathrm{C}_{\mathrm{S}-\mathrm{SS}}\right)$ and the organic content of the leachate $\left(\mathrm{C}_{\mathrm{org}}\right)$.

\subsubsection{Comparison of Leachate Quality with Other Sites}

The leachate qualities obtained in this study are compared to those reported for the other landfill sites in Table 3. In the table, site conditions such as waste age, waste thickness, landfill type, and dumping method are also shown. In terms of the basic parameters, $\mathrm{COD}$ and $\mathrm{BOD}_{5}$, the Indonesian site is similar to the KM-32 landfill, the Taiwanese and Philippino sites are close to the Nonthaburi and Dangkor Area A-B landfills, and the Indian site contains higher organic matter than the others but similar EC to that of the Nonthaburi and Dangkor leachates. Regarding the heavy metal concentrations, only one type of concentration was reported for each compared site on either filtered sample concentration, which is equivalent to the liquid part concentrations, or no specification was made regarding the type. Although the available data are very limited, the liquid part concentrations from the compared sites have the same range as those of the study sites. The unspecified concentrations at the Indian site are much larger than the liquid part concentrations of the other sites and in a similar range as the total $\mathrm{HM}$ concentrations of the study sites. However, in detail, relatively higher $\mathrm{Pb}$ and lower $\mathrm{Cd}$ were observed for the Indian site than the study sites.

Table 3. Summary of the leachate quality of different landfills (units are in $\mathrm{mg} / \mathrm{L}$, unless specified).

\begin{tabular}{|c|c|c|c|c|c|c|c|}
\hline Parameter & Nonthaburi DL & Dangkor DL.B & KM-32 DL & Indonesia [59] & Philippines [60] & Taiwan [61] & India [41] \\
\hline Age* & Mid & Mid & Young-Mid & Old & Old & Mid & Old \\
\hline $\begin{array}{c}\text { Waste } \\
\text { thickness (m) }\end{array}$ & 25 & 20 & 6 & - & 40 & - & 20 \\
\hline Landfill type & Semi-sanitary & $\begin{array}{l}\text { Controlled } \\
\text { dump }\end{array}$ & Open dump & Open dump & $\begin{array}{l}\text { Controlled } \\
\text { dump }\end{array}$ & Semi-sanitary & Open dump \\
\hline $\begin{array}{c}\text { Dumping } \\
\text { method }\end{array}$ & Trench method & Trench method & $\begin{array}{l}\text { Trench } \\
\text { method }\end{array}$ & - & Semi-canyon & $\begin{array}{l}\text { Trench } \\
\text { method }\end{array}$ & $\begin{array}{l}\text { Trench } \\
\text { method }\end{array}$ \\
\hline $\mathrm{pH}$ & $7.3 \sim 8.0$ & $7.9 \sim 8.3$ & $7.0 \sim 7.9$ & $6.8 \sim 7.5$ & 7.9 & $7.3 \sim 8.4$ & 6.9 \\
\hline $\mathrm{EC}(\mathrm{mS} / \mathrm{cm})$ & $20.3 \sim 38.8$ & $15 \sim 40.6$ & $3.2 \sim 14.5$ & - & - & $7 \sim 40.6$ & 24.5 \\
\hline TDS & $6800 \sim 23,500$ & $8100 \sim 24,800$ & $2000 \sim 7000$ & - & - & & 27,950 \\
\hline COD & $2050 \sim 7750$ & $2100 \sim 7900$ & $350 \sim 1080$ & $290 \sim 350$ & 6904 & 2480 & 27,200 \\
\hline $\mathrm{BOD}_{5}$ & $410 \sim 1230$ & - & $120 \sim 200$ & $145 \sim 218$ & - & $26 \sim 492$ & 19,000 \\
\hline As (Liq) & $0.096 \sim 0.33$ & $0.075 \sim 0.20$ & $0.048 \sim 0.079$ & - & 0.022 & - & \multirow[t]{2}{*}{ - } \\
\hline As (Total) & $0.62 \sim 0.94$ & $0.30 \sim 0.70$ & $0.23 \sim 0.33$ & & & & \\
\hline $\mathrm{Pb}$ (Liq) & $0.03 \sim 0.10$ & $0.012 \sim 0.074$ & $0.016 \sim 0.057$ & - & 0.04 & $0.0005 \sim 0.09$ & \multirow{2}{*}{$1.54^{\$}$} \\
\hline $\mathrm{Pb}$ (Total) & $0.38 \sim 0.66$ & $0.29 \sim 0.63$ & $0.16 \sim 0.19$ & & & & \\
\hline $\mathrm{Cd}(\mathrm{Liq})$ & $0.0029 \sim 0.0048$ & $0.0030 \sim 0.0050$ & $0.0015 \sim 0.0042$ & - & $<0.003$ & $<0.01$ & \multirow{2}{*}{$0.06^{\$}$} \\
\hline Cd (Total) & $0.13 \sim 0.30$ & $0.09 \sim 0.21$ & $0.05 \sim 0.08$ & & & & \\
\hline $\mathrm{Cr}$ (Liq) & $0.32 \sim 0.44$ & $0.034 \sim 0.49$ & $0.02 \sim 0.15$ & $0.04 \sim 0.05$ & 0.11 & $0.12 \sim 0.52$ & \multirow{2}{*}{$0.29^{\$}$} \\
\hline Cr (Total) & $0.71 \sim 1.02$ & $0.62 \sim 1.10$ & $0.19 \sim 0.38$ & & & & \\
\hline Zn (Liq) & $0.39 \sim 0.80$ & $0.53 \sim 0.68$ & $0.13 \sim 0.19$ & $0.05 \sim 0.06$ & - & $0.003 \sim 0.56$ & \multirow{2}{*}{$2.21^{\$}$} \\
\hline Zn (Total) & $1.35 \sim 1.60$ & $0.88 \sim 1.44$ & $0.31 \sim 0.51$ & & & & \\
\hline
\end{tabular}

*: Young $=$ age $<5 \mathrm{yrs} ;$ Mid-age $=5<$ age $<10 ;$ Old $=$ age $>10, \$$ : no explanation of type of concentration. 
Due to the lack of information on the influential factors and conditions, it is very difficult to identify the crucial factors on the leachate quality. However, it can be said that the continuing accumulation of the various leachate quality data together with site conditions is of vital importance for the improvement of solid waste management in developing countries.

\subsection{Sediment Characterization}

Sediment samples were collected at the DL and LDP sampling points of the Nonthaburi landfill and the DL.B sampling points of the Dangkor landfill. As in the KM-32 landfill, there was no cover soil placed on the waste and no sediments accumulated in the dumping area, the sediment samples were only collected at the natural wetland (WL). The particle size distribution and organic contents of the sediment samples were measured by sieve analysis and ignition loss test. The same set of heavy metals $(\mathrm{As}, \mathrm{Pb}, \mathrm{Cd}, \mathrm{Cr}$ and $\mathrm{Zn}$ ) as measured for the total and liquid part of the leachate were also investigated for the sediments. Figure 14 shows the fractions of organic and non-organic matter, and the fine and coarse particles of the sediments. The organic contents were about $9-10 \%$ for the DL samples of the Nonthaburi and Dangkor sites and the WL sample of the KM-32 site, while it was 17\% for the LDP samples of the Nonthaburi landfill. These organic contents are much smaller than those in the SS of the leachate (Figure $6 \mathrm{~b}$ ). The fine particle fraction of the Dangkor landfill sample was the lowest, at about $50 \%$. The erosion of the new cover soils of Area A-B, containing a relatively large sand fraction, is the reason for the low fine particle fraction. Nonetheless, all sediment samples contained quite a significant amount of fine particles, at more than $50 \%$. This large fine particle content could be a cause of high heavy metal adsorption in the sediment due to the large surface area of the interface [62].

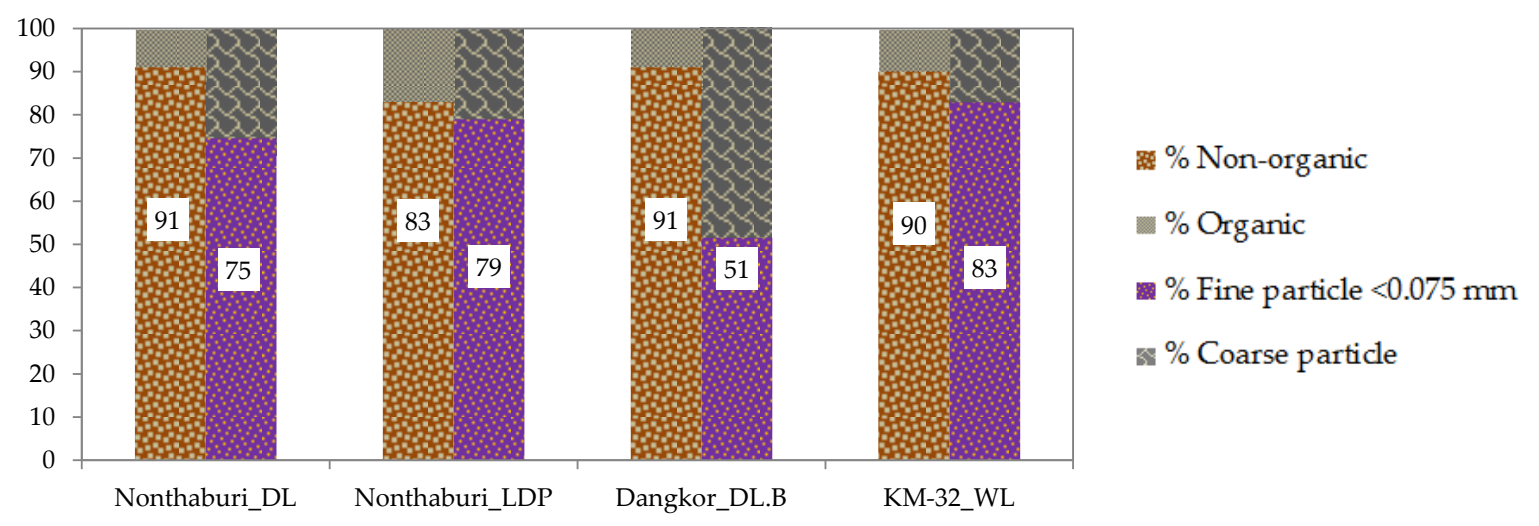

Figure 14. Organic and non-organic fraction and fine and coarse particle fractions of the sediments.

Figure 15 presents the heavy metal contents $\left(\mathrm{C}_{\mathrm{S}}\right)$ of the sediment samples together with that of the suspended solids of the leachate (SS) for comparison. All HM contents of the sediments were higher than that of the suspended solids, about 1.5-5 times, except for arsenic, which was about 1.2-1.5 times higher. The sediments contained a relatively large amount of fine particles, as discussed above, which could capture HMs better than the SS of the leachate. Also regarding the sediments, the highest contents for most of the heavy metals was observed for the DL sampling points at the Nonthaburi site. However, as a general trend, the differences in the HM contents of the sediment and the SS were larger for the LDP and WL samples than the DL samples, both in the Nonthaburi and KM32 landfills. This could be attributed to the accumulation effects in the leachate storage. As a result, the differences in the HM contents in the sediments between the sites, as well as the locations, were smaller than that of HM contents of the SS. 


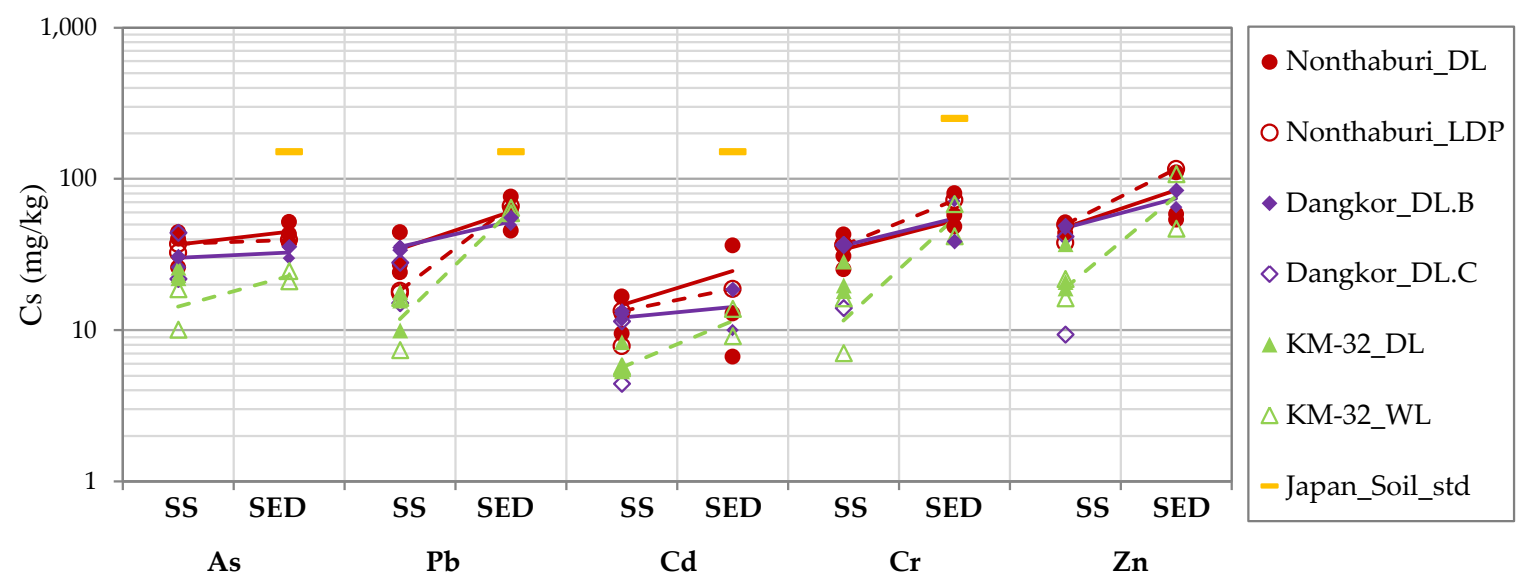

Figure 15. The heavy metal contents of the suspended solids of the leachate (SS) and sediment (SED).

All the observed HM contents of the sediment were lower than the limit specified by the Soil Contamination Countermeasure Act of Japan [63], which is shown as "Japan_Soil_std". Similarly to the HM contents of the SS (Figure 10), no evident seasonal change was confirmed in the sediment, as was also discussed in a previous study [64]. The observed ranges of HM contents in the SS and sediments are summarized in Table 4, with the reported range of HM contents in the normal soils [65]. Almost all the observed HM contents are in the range of normal soil, except for $\mathrm{Cd}$, which was larger than the normal soil. The relatively high organic contents compared to the normal inorganic soil could be a possible reason for the large $\mathrm{Cd}$ content.

Table 4. The HM contents of this study and that commonly found in normal soils ( $\mathrm{mg} / \mathrm{kg}$ ).

\begin{tabular}{|c|c|c|c|c|c|c|c|c|c|c|}
\hline \multirow{2}{*}{$\begin{array}{l}\text { Heavy } \\
\text { Metal }\end{array}$} & \multicolumn{4}{|c|}{ Nonthaburi Landfill } & \multicolumn{2}{|c|}{ Dangkor Landfill } & \multicolumn{2}{|c|}{ KM-32 Landfill } & \multicolumn{2}{|c|}{ Normal Soil [65] } \\
\hline & DL_SS & DL_SED & LDP_SS & LDP_SED & DL.B_SS & DL.B_SED & DL_SS & WL_SED & Ave & Range \\
\hline As & $26-45$ & $37-52$ & $32-37$ & 39.5 & $25-31$ & $30-35$ & $22-26$ & $21-25$ & 7.2 & $0.1-55$ \\
\hline $\mathrm{Cr}$ & $25-43$ & $48-80$ & $36-37$ & 72.4 & $35-37$ & $38-71$ & $18-28$ & $42-68$ & 40 & $10-150$ \\
\hline $\mathrm{Pb}$ & $24-44$ & $45-76$ & $17-18$ & 66.2 & $33-36$ & $50-55$ & $9-18$ & $59-64$ & - & $2-300$ \\
\hline $\mathrm{Cd}$ & $10-16$ & $6-36$ & $8-13$ & 18.7 & $11-13$ & $10-18$ & $5-8$ & $9-14$ & 0.35 & $0.001-2$ \\
\hline $\mathrm{Zn}$ & $44-51$ & $53-110$ & $37-50$ & 116.2 & $46-49$ & $64-83$ & $19-37$ & $46-107$ & 90 & $1-900$ \\
\hline
\end{tabular}

The large leachate storage pond in the Nonthaburi landfill (LDP) could accumulate a massive volume of contaminated sediments at the bottom, which could be a source of contaminants in the future. For the proper estimation of the future risk associated with the sediments, quality and quantity investigations are necessary, including a TCLP (toxicity characteristic leaching procedure) [66] of the sediments. Then, depending on the evaluated risk, the treatment or removal of the sediments would be a main concern, together with the treatment of a huge volume of the leachate stored in the LDP for the rehabilitation of the Nonthaburi landfill site after the closure of the landfill.

\section{Conclusions}

Leachate and sediment samples were collected from three tropical landfills in Indochina peninsular countries-Nonthaburi province landfill in Thailand, Dangkor landfill, Phnom Penh City in Cambodia, and the KM-32 landfill, Vientiane City in Laos-and assessed by in-situ and laboratory measurements. The landfills have received similar waste through the same disposal method, i.e., excavated deep pits on the low permeable geological barrier. The key findings from the study are listed as follows:

(1) Most of the basic biological and chemical parameters of the fresh leachates showed higher concentrations in the dry seasons than in the wet seasons, while no significant seasonal variations were found in the samples taken from a large leachate pond. Most of the parameters showed high 
concentration compared to the industrial effluent standard, especially the leachate from the Nonthaburi landfill and the Dangkor closed landfill.

(2) Positive correlations of the leachate quality parameters are confirmed for both the physical and chemical properties, such as suspended concentration $\left(\mathrm{C}_{\mathrm{SS}}\right)$ and solid concentration $\left(\mathrm{C}_{\text {solid }}\right)$, organic content $\left(\mathrm{C}_{\text {org }}\right)$ and $\mathrm{C}_{\mathrm{SS}}$, chloride concentration and TDS, $\mathrm{BOD}_{5}$ and $\mathrm{COD}, \mathrm{COD}$ and TDS, and COD and $\mathrm{C}_{\mathrm{SS}}$.

(3) The total heavy metal concentration of the leachates were about 2 to 50 times larger than the dissolved heavy metal concentrations in the liquid part of the leachates, implying that the major part of the heavy metal (HM) contents in the leachates, about 50 to $99 \%$, are partitioned in the suspended solids.

(4) The total and the dissolved liquid part HM concentrations of the leachates are several times higher than the industrial effluent and groundwater standard, respectively, suggesting that there are risks of surface water and groundwater contamination under the current landfill management practices, for example no leachate collection or treatment facilities and high leachate levels in the deep disposal pit. However, considering the fact that a significant portion of the heavy metals in the leachates is partitioned to the suspended solids (SS), simple physical filtration or sedimentation of the SS from the leachate could significantly decrease the total HM. Such a simple treatment could reduce the pollution risk to the surrounding water and soil.

(5) The partitioning of heavy metals on the suspended solids of the leachates is affected by many factors. Although clear isotherm could not be obtained from the relationship between the liquid part HM concentration and the SS part HM contents, mainly due to the unknown conditions of the SS and the adsorbing process, the effect of the liquid part concentration, type of HM, and organic contents can be confirmed from the various measurements.

(6) No significant seasonal variations of HM contents was observed for the sediment and the suspended solids of the leachate. The heavy metal content per unit solid mass was about 1.2-5 times higher for the sediments than the suspended solids. Considering the large volume of sediments and relatively high HM contents, the sediments could be a future risk of groundwater contamination, especially for the large leachate discharge pond on the Nonthaburi landfill site.

Author Contributions: All authors contributed equally to the general results of this research.

Funding: This work was supported by the JSPS Core-to-Core Program, B. Asia-Africa Science Platforms.

Acknowledgments: Special thanks to the landfill authorities of the Nonthaburi, Dangkor, and KM-32 landfill for their support and for providing the necessary information on the landfills.

Conflicts of Interest: The authors declare no conflict of interest.

\section{References and Note}

1. Pariatamby, A.; Tanaka, M. MSW Management in Asia and the Pacific Islands-Challenge and Strategic Solution; Environmental Science and Engineering, Springer: Singapore, 2014.

2. Ziadat, A.H.; Mott, H. Assessing solid waste recycling opportunities for closed campuses. Manag. Environ. Qual. 2005. [CrossRef]

3. El-Fadel, M.; Findikakis, A.N.; Leckie, J.O. Environmental impacts of solid waste landfilling. J. Environ. Manag. 1997, 50, 1-25. [CrossRef]

4. Kjeldsen, P.; Barlaz, M.A.; Rooker, A.P.; Baun, A.; Ledin, A.; Christensen, T.H. Present and long-term composition of MSW landfill leachate: A review. Crit. Rev. Environ. Sci. Technol. 2002, 32, 297-336. [CrossRef]

5. Ole, H.; Lizzi, A.; Jette, B.H. Leachate emission from landfill. In Final Report Swedish Environmental Protection Agency; Naturvårdsverket: Stockholm, Sweden, 2000; ISSN 1102-6944. Available online: https://www. naturvardsverket.se/Documents / publikationer/afr-r-265-se.pdf?pid=4394 (accessed on 10 October 2016).

6. Kanmani, S.; Gandhimathi, R. Assessment of heavy metal contamination in soil due to leachate migration from an open dumping site. Appl. Water Sci. 2013, 3, 193-205. [CrossRef]

7. Slack, R.J.; Gronow, J.R.; Voulvoulis, N. Household hazardous waste in municipal landfills: Contaminants in leachate. Sci. Total Environ. 2005, 337, 119-137. [CrossRef] [PubMed] 
8. Umar, M.; Aziz, H.A.; Yusoff, M.S. Variability.002. of Parameters Involved in Leachate Pollution Index and Determination of LPI from Four Landfills in Malaysia. Int. J. Chem. Eng. 2010, 2010, 6. [CrossRef]

9. Yarlagadda, P.S.; Matsumoto, M.R.; VanBenschoten, J.E.; Kathuria, A. Characteristics of heavy metals in contaminated soils. J. Environ. Eng. 1995, 121, 276-286. [CrossRef]

10. Waheed, S.; Siddique, N.; Hamid, Q.; Chaudhry, M.M. Assessing soil pollution from a municipal waste dump in Islamabad, Pakistan: A study by INAA and AAS. J. Radioanal. Nucl. Chem. 2010, 285, 723-732. [CrossRef]

11. Iwegbue, C.M.A.; Nwajei, G.E.; Ogala, J.E.; Overah, C.L. Determination of trace metal concentrations in soil profiles of municipal waste dumps in Nigeria. Environ. Geochem. Health 2010, 32, 415-430. [CrossRef] [PubMed]

12. Bretzel, F.C.; Calderisi, M. Contribution of a municipal solid waste incinerator to the trace metals in the surrounding soil. Environ. Monit. Assess. 2011, 182, 523-533. [CrossRef] [PubMed]

13. Rizo, O.D.; Merlo, M.H.; Castillo, F.E.; Lopez, J.A.O. Assessment of metal pollution in soils from a former Havana (Cuba) solid waste open dump. Bull. Environ. Contam. Toxicol. 2012, 88, 182-186. [CrossRef] [PubMed]

14. Looser, M.O.; Parriaux, A.; Bensimon, M. Landfill underground pollution detection and characterization using inorganic traces. Water Res. 1999, 33, 3609-3616. [CrossRef]

15. Abu-Rukah, Y.; Al-Kofahi, O. The assessment of the effect of landfill leachate on groundwater quality-A case study: El-Akader Landfill Site-North Jordan. Arid Environ. 2001, 49, 615-630. [CrossRef]

16. Saarela, J. Pilot investigations of surface parts of three closed landfills and factors affecting them. Environ. Monit. Assess. 2003, 84, 183-192. [CrossRef] [PubMed]

17. Aderemi, A.O.; Oriaku, A.V.; Adewumi, G.A.; Otitoloju, A.A. Assessment of groundwater contamination by leachate near a municipal solid waste landfill. Afr. J. Environ. Sci. Technol. 2011, 5, 933-940. [CrossRef]

18. Magda, M.A.; Gaber, I.A. Impact of landfill leachate on the groundwater quality: A case study in Egypt. J. Adv. Res. 2015, 6, 579-586. [CrossRef]

19. World Weather and Climate Information. Available online: https://weather-and-climate.com/averagemonthly-Rainfall-Temperature-Sunshine,Bangkok, Thailand (accessed on 15 December 2016).

20. Japan International Cooperation Agency (JICA). The Study on Solid Waste management in the Municipality of Phnom Penh, Kingdom of Cambodia; JICA: Tokyo, Japan, 2005.

21. Miyano, N. Study on Environmental assessment of groundwater and surface water in landfill, Nonthaburi Province, Thailand. Master's Thesis, Department of Civil Engineering, Tokyo Institute of Technology, March 2016.

22. United Nations Environment Programme. Newsletter and Technical Publication for Landfill, Classification (6.3). Available online: http:/ / www.unep.or.jp/Ietc/ESTdir/Pub/MSW/SP/SP6/SP6_3.asp (accessed on 15 December 2017).

23. Irfa'i; Yanuwiadi, B.; Suyadi. Landfills Leachates Quality and Quantity in Tidal Area in Banjarmasin Landfills, Indonesia. Resour. Environ. 2016, 6, 23-27. [CrossRef]

24. Kathirvale, S.; Yunus, M.N.M.; Sopian, K.; Samsuddin, A.H. Energy potential from municipal solid waste in Malaysia. Renew. Energy 2003, 29, 559-567. [CrossRef]

25. Nguyen, N.U.; Schnitzer, H. Sustainable solutions for solid waste management in Southeast Asian countries. Waste Manag. 2009, 29, 1982-1995. [CrossRef]

26. Verma, R.L.; Borongana, G.; Memonb, M. Municipal Solid Waste Management in Ho Chi Minh City, Viet Nam, Current Practices and Future Recommendation. Procedia Environ. Sci. 2016, 35, 127-139. [CrossRef]

27. Feniel, P.; Culot, M. Household solid waste generation and characteristics in Cape Haitian city, Republic of Haiti. Resour. Conserv. Recycl. 2009, 54, 73-78. [CrossRef]

28. Sujauddin, M.; Huda, S.M.S.; Rafiqul-Hoque, A.T.M. Household solid waste characteristics and management in Chittagong, Bangladesh Waste. Management 2008, 28, 1688-1695. [CrossRef] [PubMed]

29. Sha'Ato, R.; Aboho, S.Y.; Oketunde, F.O.; Eneji, I.S.; Unazi, G.; Agwa, S. Survey of solid waste generation and composition in a rapidly growing urban area in Central Nigeria. Waste Manag. 2007, 27, 352-358. [CrossRef] [PubMed]

30. Waste Composition survey. Site Engineer Presentation Report of Nonthaburi Landfill during our site visit and interview.

31. Siengheng, H. Phnom Penh Solid Waste Survey Project Report; Dangkor landfill: Battambang, Cambodia, 2015. 
32. JCM/BOCM Feasibility Study Report; KM-32 landfill: Vientiane, Laos, 2012.

33. ASTM D 2974-87 Standard Test Methods for Moisture, Ash, and Organic Matter of Peat and Other Organic Soil. Available online: http:/ / gsrpdf.lib.msu.edu/ticpdf.py?file=/1990s /1993/930331.pdf (accessed on 27 April 2018).

34. Ziyang, L.; Youcai, Z.; Tao, Y.; Yu, S.; Huili, C.; Nanwen, Z.; Renhua, H. Natural attenuation and characterization of contaminants composition in landfill leachate under different disposing ages. Sci. Total. Environ. 2009, 407, 3385-3391. [CrossRef] [PubMed]

35. Salem, Z.; Hamouri, K.; Djemaa, R.; Allia, K. Evaluation of landfill leachate pollution and treatment. Desalination 2008, 220, 108-114. [CrossRef]

36. Aziz, S.Q.; Aziz, H.A.; Bashir, M.J.K.; Mojiri, A. Assessment of various tropical municipal landfill leachate characteristics and treatment opportunities. Glob. NEST J. 2015, 17, 439-450.

37. Aziz, S.Q.; Aziz, H.A.; Bashir, M.J.K.; Yusoff, M.S.; Umar, M. Leachate characterization in semi-aerobic and anaerobic sanitary landfills: A comparative study. J. Environ. Manag. 2010, 91, 2608-2614. [CrossRef] [PubMed]

38. Ghafari, S.; Aziz, H.A.; Bashir, M.J.K. The use of poly-aluminum chloride and alum for the treatment of partially stabilized leachate: A comparative study. Desalination 2010, 257, 110-116. [CrossRef]

39. Aghamohammadi, N.; Aziz, H.A.; Isa, M.H.; Zinatizadeh, A.A.; Nasrollahzadeh, S.H.; Ghafari, S. Performance of a powdered activated carbon (PAC) augmented activated sludge process treating semi-aerobic leachate. Int. J. Environ. Res. 2007, 1, 96-103.

40. Agatha, A.N. Water quality and micro-organisms of leachate-contaminated pond. Am. J. Sci. Ind. Res. 2011, 2, 205-208. [CrossRef]

41. Bashir, M.J.K.; Aziz, H.A.; Yusoff, M.S.; Adlan, M.N. Application of response surface methodology (RSM) for optimization of ammoniacal nitrogen removal from semi-aerobic landfill leachate using ion exchange resin. Desalination 2010, 254, 154-161. [CrossRef]

42. Mor, S.; Ravindra, K.; Dahiya, R.P.; Chandra, A. Leachate characterization and assessment of groundwater pollution near municipal solid waste landfill site. Environ. Monit. Assess. 2006, 118, 435-456. [CrossRef] [PubMed]

43. Bhalla, B.; Saini, M.S.; Jha, M.K. Effect of age and seasonal variations on leachate characteristics of municipal solid waste landfill. Int. J. Res. Eng. Technol. 2013. [CrossRef]

44. Industrial Estate Authority of Thailand (IEAT). Industrial Effluent Standard for Industrial Plants and Industrial Estates; IEAT: Bangkok, Thailand, 2016.

45. Ministry of Environment, Kingdom of Cambodia, MOEC. Sub-Decree on Water Pollution Control, Kingdom of Cambodia; MOEC: Phnom Penh, Cambodia, 1999.

46. Ministry of Natural Resources and Environment, Laos, MONREL. National Environmental Standard of Laos; MONREL: Vientiane, Laos, 2009.

47. Ministry of the Environment, Government of Japan. Uniform National Effluent Standards; Ministry of the Environment: Tokyo, Japan, 2015; latest update version.

48. Christensen, T.H.; Kjeldsen, P.; Bjerg, P.L.; Jensen, D.L.; Christensen, J.B.; Baun, A.; Albrechtsen, H.J.; Heron, G. Biogeochemistry of landfill leachate plumes. Appl. Geochem. 2001, 16, 659-718. [CrossRef]

49. Zhong, Q.; Li, D.; Tao, Y.; Wang, X.; He, X.; Zhang, J.; Zhang, J.; Guo, W.; Wang, L. Nitrogen removal from landfill leachate via ex-situ nitrification and sequential in situ denitrification. Waste Manag. 2009, 29, 1347-1353. [CrossRef] [PubMed]

50. Canziani, R.; Emondi, V.; Garavaglia, M.; Malpei, F.; Pasinetti, E.; Buttiglieri, G. Effect of oxygen concentration on biological nitrification and microbial kinetics in a cross-flow membrane bioreactor (MBR) and moving-bed biofilm reactor (MBBR) treating old landfill leachate. J. Memb. Sci. 2006, 286, 202-212. [CrossRef]

51. Weiner, R.F.; Matthews, R. Environmental Engineering, 4th ed.; Butterworth Heinemann: Oxford, UK, 2003.

52. Aziz, H.A.; Alias, S.; Adlan, M.N.; Asaari, F.A.H.; Zahari, M.S.M. Colour removal from landfill leachate by coagulation and flocculation processes. Bioresour. Technol. 2007, 98, 218-220. [CrossRef] [PubMed]

53. Tanchuling, M.N.; Cayabyab, I.D.; Takemura, J. Investigation leachate contamination near Quezon City controlled dumping facility (QCCDF) using chloride ion as indicator. ASEAN Eng. J. 2015, 4, 112-125.

54. Bashir, M.J.K.; Isa, M.H.; Kutty, S.R.M.; Awang, Z.B.; Aziz, H.A.; Mohajeri, S.; Farooqi, I.H. Landfill leachate treatment by electrochemical oxidation. Waste Manag. 2009, 29, 2534-2541. [CrossRef] [PubMed] 
55. Parth, V.; Murthy, N.N.; Saxena, P.R. Assessment of heavy metal contamination in soil around hazardous waste disposal sites in Hyderabad city, India: Natural and anthropogenic implications. J. Environ. Res. Manag. 2011, 2, 27-34.

56. Moturi, M.C.Z.; Rawat, M.; Subramanian, V. Distribution and fractionation of heavy metals in solid waste from selected sites in the industrial belt of Delhi. Environ. Monit. Assess. 2004, 95, 183-199. [CrossRef] [PubMed]

57. Elliott, H.A.; Liberati, M.R.; Huang, C.P. Competitive adsorption of heavy metals by soils. J. Environ. Qual. 1986, 15, 214-219. [CrossRef]

58. Renou, S.; Givaudan, J.G.; Poulain, S.; Dirassouyan, F.; Moulin, P. Landfill leachate treatment: Review and opportunity. J. Hazard. Mater. 2008, 150, 468-493. [CrossRef] [PubMed]

59. Yusmartini1, E.S.; Setiabudidaya, D.; Ridwan; Marsi; Faizal. Characteristics of Leachate at Sukawinatan Landfill, Palembang, Indonesia. J. Phys. Conf. Ser. 2013, 423, 012048. [CrossRef]

60. Kusakabe, O.; Aramrak, T.; Sigua, G.R.; Takemura, J.; Diola, B.N.; Yodsudjai, W. Sustainable Civil Engineering. Harmonizing Infrastructure Development with the Environment; University of the Philippines: Diliman, Philippines, 2009.

61. Fan, H.J.; Shu, H.Y.; Yang, H.S.; Wen-Ching Chen, W.C. Characteristics of landfill leachates in central Taiwan. Sci. Total Environ. 2006, 361, 25-37. [CrossRef] [PubMed]

62. Parizanganeh, A. Grain size effect on trace metals in contaminated sediments along the Iranian Coast of Caspian Sea. In Proceedings of the Taal 2007: The 12th Wor Lake Conference, Jaipur, India, 28 October-2 November 2007; pp. 329-336.

63. Soil Contamination Countermeasures Act-Soil Environment Management Division, Ministry of the Environment, Government of Japan. 2007. Available online: http://www.env.go.jp/en/water/soil/ contami_cm.pdf (accessed on 15 December 2017).

64. Olubunmi, F.E.; Olorunsola, O.E. Evaluation of the status of heavy metal pollution of sediment of Agbabu Bitumen deposit area, Nigeria. Eur. J. Sci. Res. 2010, 41, 373-382.

65. Bradl, H.B. Heavy Metals in Environment: Origin, Interaction and Remediation; Elsevier: New York, NY, USA, 2005; pp. 1047-1609.

66. SW-846 Test Method 1311: Toxicity Characteristic Leaching Procedure. Available online: https:// www.epa.gov/hw-sw846/sw-846-test-method-1311-toxicity-characteristic-leaching-procedure (accessed on 15 December 2017).

(C) 2018 by the authors. Licensee MDPI, Basel, Switzerland. This article is an open access article distributed under the terms and conditions of the Creative Commons Attribution (CC BY) license (http:/ / creativecommons.org/licenses/by/4.0/). 